\title{
دراسة أثر الأفلام القصيرة على الجتمع السعودي
}

\author{
إعداد \\ هد / هشام عبد الرحمــ محمود مغربحــ \\ أستاذ مشارك التصميم الجرافيكى والوسائط الرقمية \\ جامعة أم القرى السعودية \\ د / ربا حسر أمين أبو حسنة \\ أستاذ مساعد التصميم الجرافيكى والوسائط الرقمية \\ كلية جدة العالمية
}

مجلة بحوث التربية النوعية - جامعة المنصورة

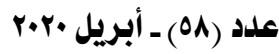




\section{دراسة أثز الأفلام القصيرة على المتهمع السعودي}

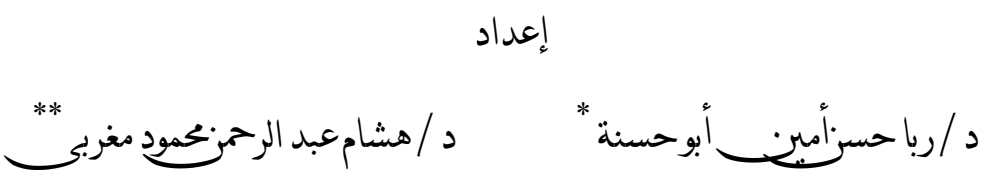

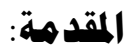

مرت المجتمعات البشرية بعدة مراحل من التطور العلهي ,حيث كان لهذه المراحل المختلفة

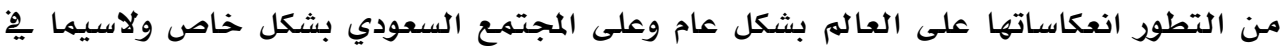

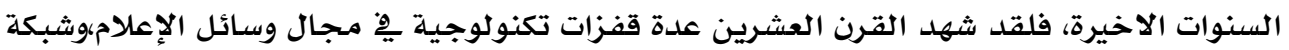

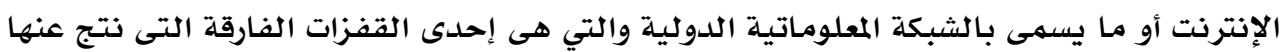

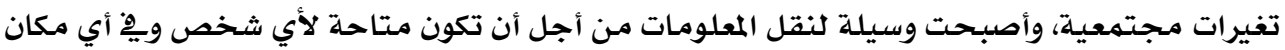

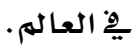

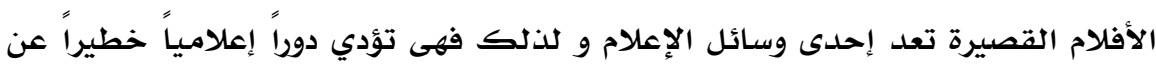

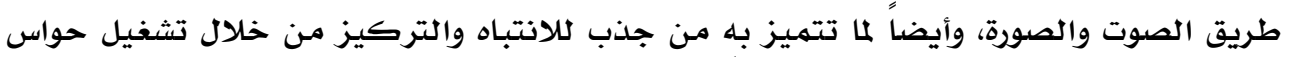

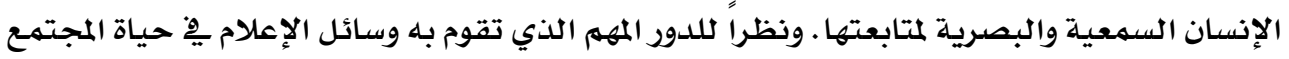

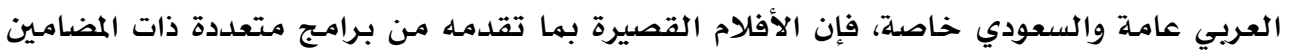

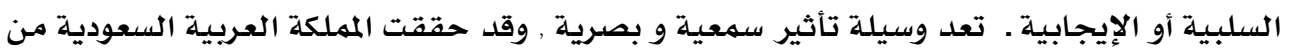

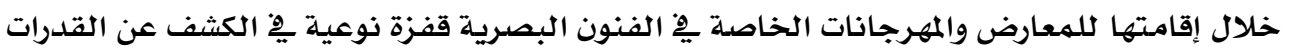

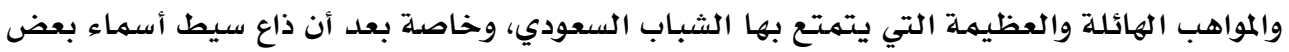

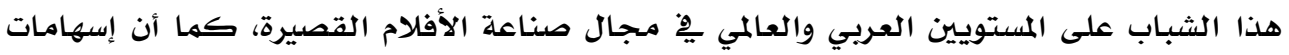

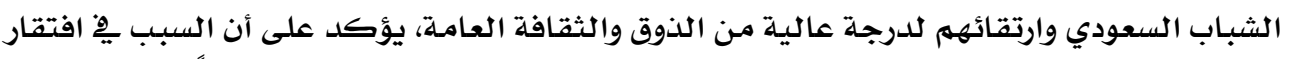

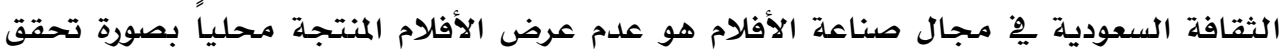
الانتشار.

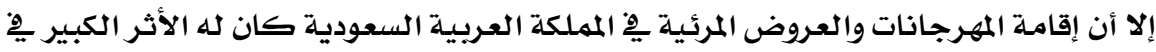

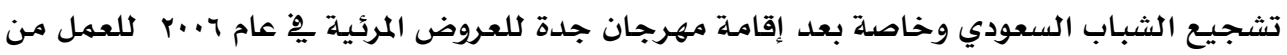

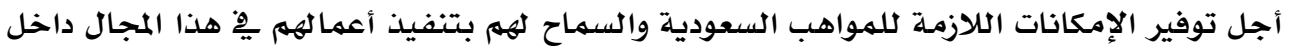

السعودية وخارجها.

* أستاذ مساعد التصميم الجرافيكى والوسائط الرقمية كلية جدة العالمية

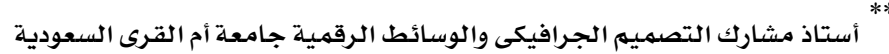


وبناء على ما تقدم فإن هذه الدراسة تتناول أثر الأفلام القصيرة على المجتهـع السعودي،

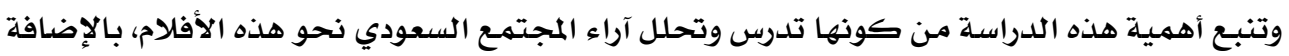

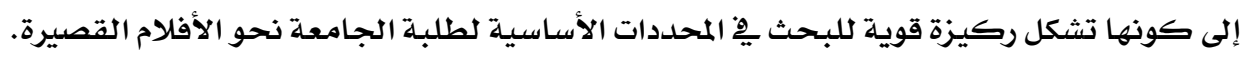

$$
\text { مشكلة الدراسـة: }
$$

تتمثل مشكلة الدراسة الحالية ِِّ التساؤل عن أسباب اهتمام عدد كبير من الشباب

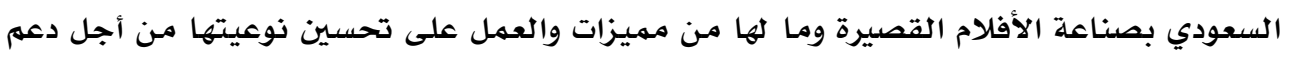

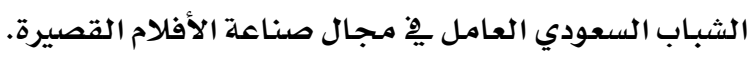

$$
\text { أسئلة الدراسةة: }
$$

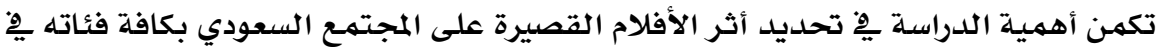

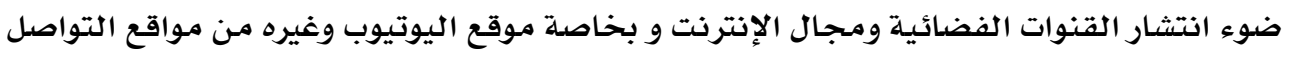

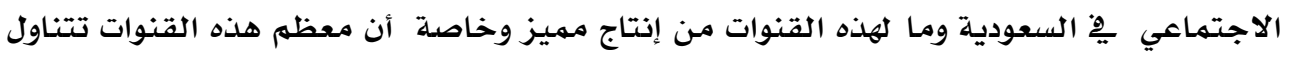
قضايا اجتماعية مختلفة.

و تستمد الدراسة أهميتها من أهمية إنتاج الأفلام السعودية القصيرة لتناولها الموضوعات ألهات

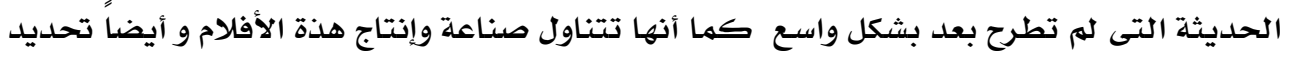

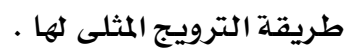

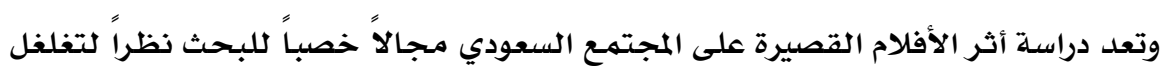

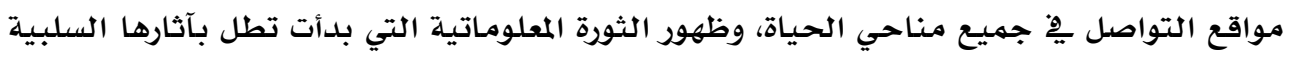

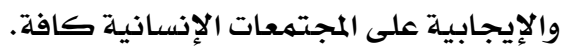

وتطمح الدراسـة إلى تكوين قاعدة معلومات وبيانات حول موضوع دراسة أثر الأفلام القصيرة

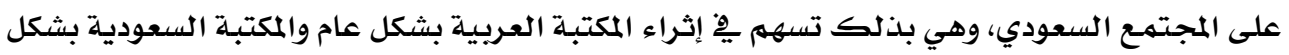

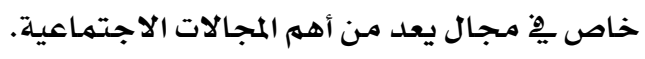
فرضيات الدراسة: اعتمدت الباحثة الفرضيات التالية: 


\section{• الفرضية الرئيسة الأولى:}

هناك فروق دالة على تأثر المجتمع السعودي بالأفلام القصيرة.

\section{• الفرضية الرئيسة الثانية:}

هناك فروق دالة بين بعض المتغيرات المحددة لعناصرالمجتهـع السعودى و مدىى تأثره بالأفلام

وتنبثق عنها الفرضيات الفرعية التالية:

ا. الفرضية الفرعية الأولى: هناك فروق ذات دلالة إحصائية يّْ دراسة أثر الأفلام القصيرة على

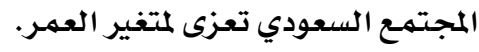

r. الفرضية الفرعية الثانية: هناك فروق ذات دلالة إحصائية ِِّْ دراسـة أثر الأفلام القصيرة على

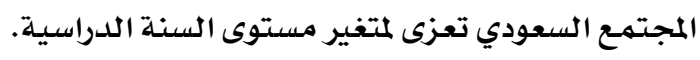

\section{أهد|ف الدراسةة:}

$$
\text { تسعى هذه الدراسة إلى تحقيق الأهداف التالية: }
$$

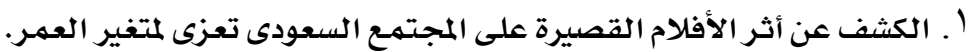

r. الكثف عن أثر الأفلام القصيرة على المجتمع السعودى تعزى لمستوى الفرقة الدراسية.

\section{هدود الدراسة:}

$$
\text { تمثلت حدود الدراسة فيما يلي: }
$$

ا. اقتصرت هذه الدراسـة على آراء عينة من طالبات جامعة الأميرة نورة بكلية التصاميم والفنون

$$
\text { حيث تم اختيار عينة عشوائية ممثلة لطالبات الكلية. }
$$

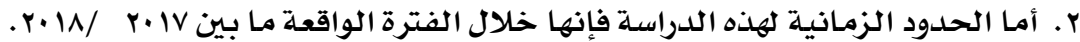

\section{مصطاح الدات الدراسة:}

\section{الأفلام القصيرة}

الفيله القصير هو مجال لشخصنة الأسلوب، فالفيلم القصير لا يشترط بـه تواجد عناصر

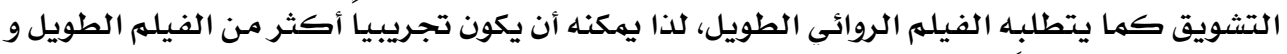

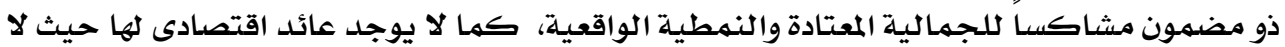
يوجد سوق لهذه الأفلام سوى المهرجانات، والمهرجانات الفنية تعشق كل من يبحث عن أصالة

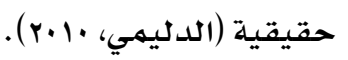

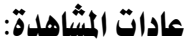


هى سلوكيات الإنسان المصاحبة لمشاهدة الأفلام القصيرة والتي يحرص على القيام به مـرارا وتكرار كلما شاهد الفيله.

\section{المبحث الثاني : الإطار النظري والدراسات السابقة}

الأفلام القصيرة

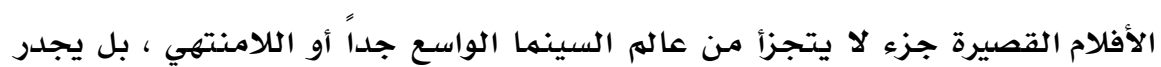

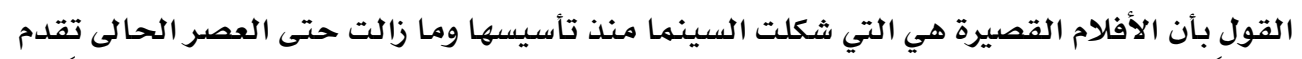

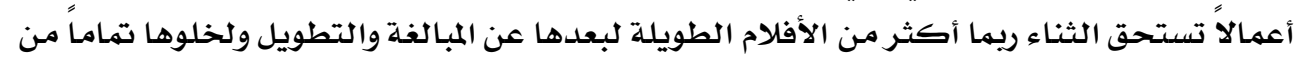

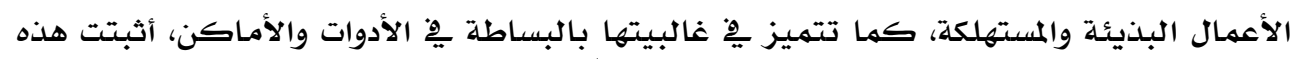

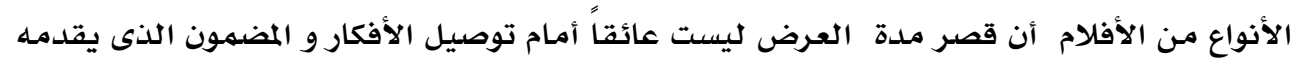

$$
\text { الفيلم المعروض. }
$$

والأفلام القصيرة كما تعرفها أكاديهية فنون و علوم الصور المتحركة ـ أوسكار. بأنها

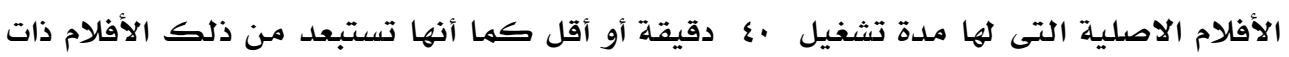

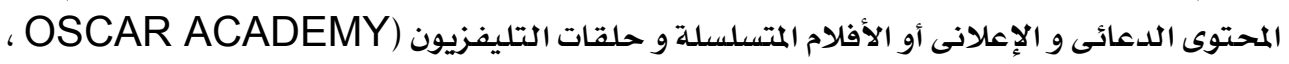

والأفلام التي تزيد مدتها عن ·ـ دقيقة تعتبر من الأفلام المتوسطة، والتي لا يمكن قبولها يِ

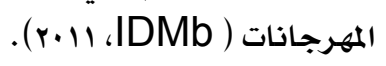

كها أن الأفلام القصيرة هي أحد الفروع المرئية والتي فيها عدة أنواع نذكر منها، الفلم

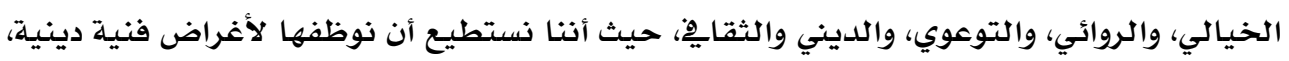

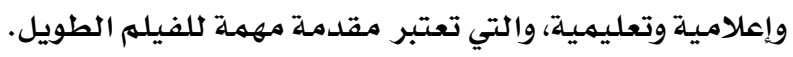

و معهد الفيلم البريطاني يعرف الفيلم القصير بأنه هو أي فيله ليس طويل بها يكفي

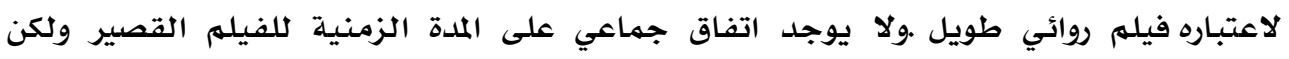

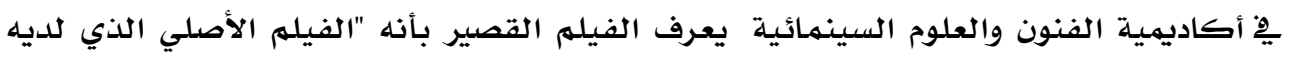

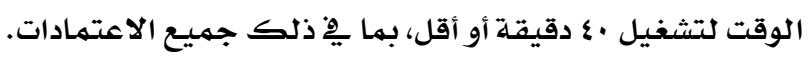

\section{ميزات الأفلام القصيرة:}

الفيلم القصير متفرد عن الفيلم الطويل فى عدة خصائص منها العناصر الدرامية تتميز

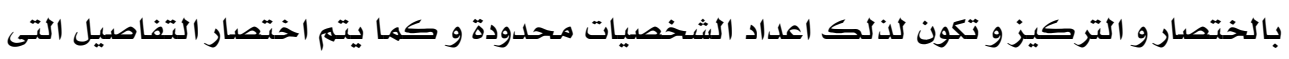

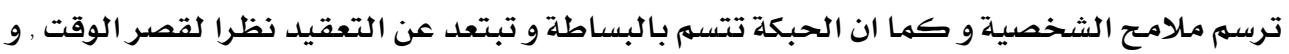

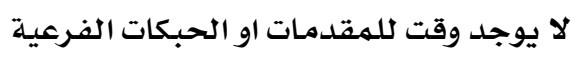

تتميز الأفلام القصيرة بسهولة طرح فكرة موضوع الفيلم وبهذا تصل رسالتها للجمهور

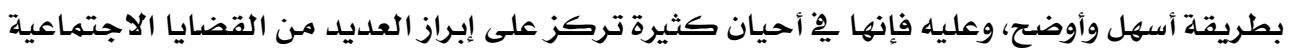

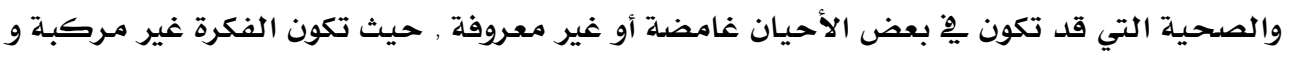


يكون الاسلوب القصصى مقتصل, كما ان الصراع فى الفيلم القصير واحلد و رئيسى ويثمل حادثة

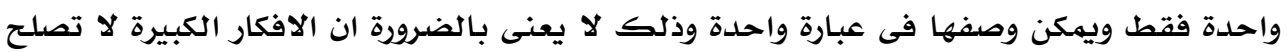

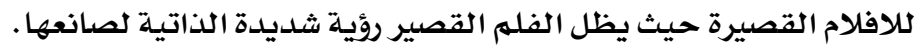
و من مميزات الفيلم القصير التحفيز ليس ضمن الاحداث و انما يحلدث بعيدا عن الثاشـة

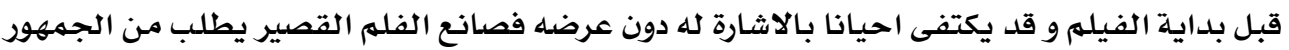

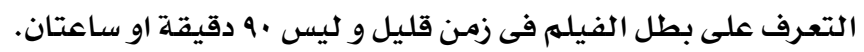
و يتميز الفيلهم القصير بالحرية فى التعبيرو استخدام المجاز او غيره من الادوات الادبية

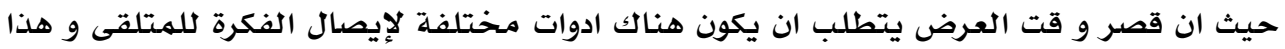

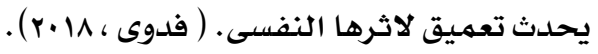

ومما يميز الأفلام القصيرة أيضاً سهولة تنفيذها وقلة الجهد والتكلفة، وسهولة توزيعها، أما الأفلام الطويلة فإن عملية إنتاجها ليست سهلة وتحتاج إلى الإمكانيات الكبيرة، وعليه فإن هذان هذه المزايا

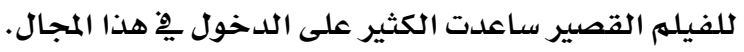
أهمية الأفلام القصيرة:

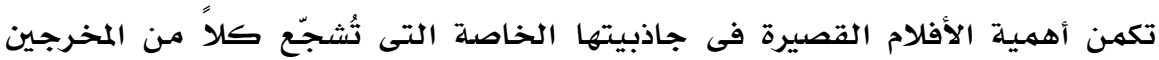

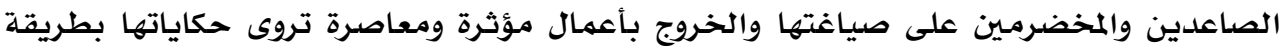

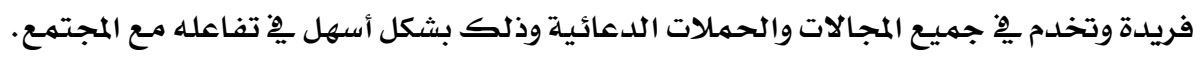
الأفلام القصيرة في السعودية

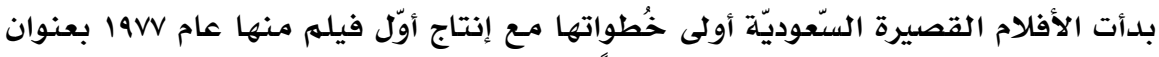

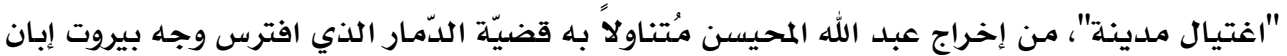

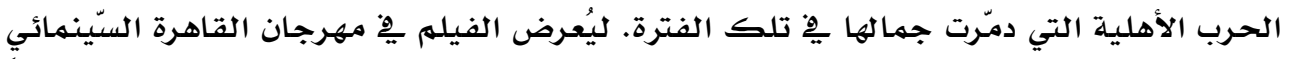

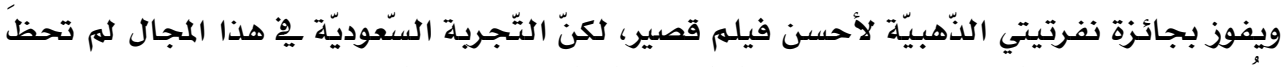

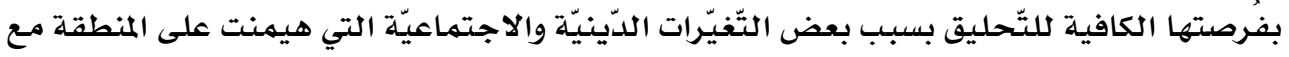

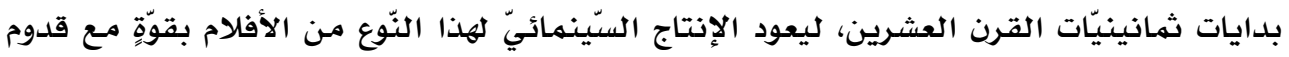

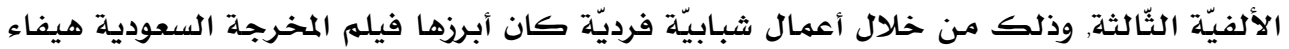

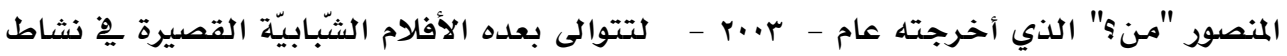

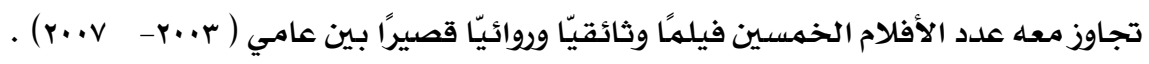
وأمام السّمعة المتصاعدة لتلك الأفلام بعد, ما حصدته من جوائز وتنويهاتٍ جديرةٍ

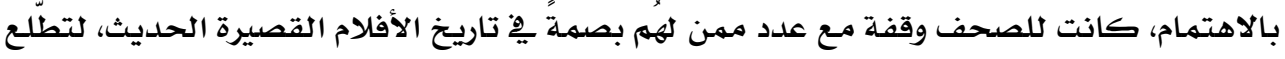

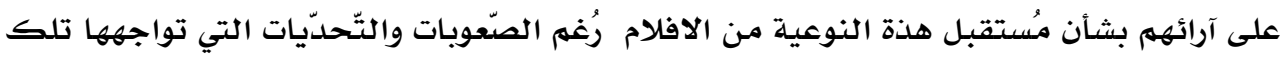

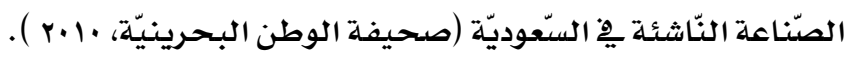


إن ما ميز الأفلام السعودية ِيْ العامـين الماضيين أنها أكثر تنوعاً ِِّ تناول القضايا

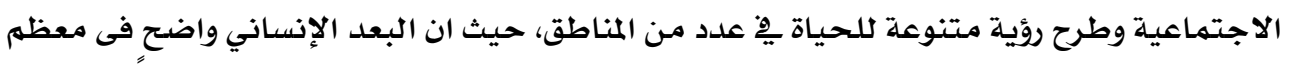

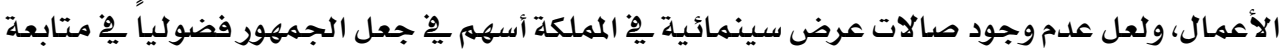

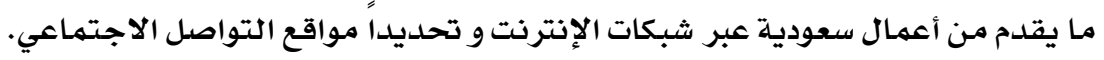

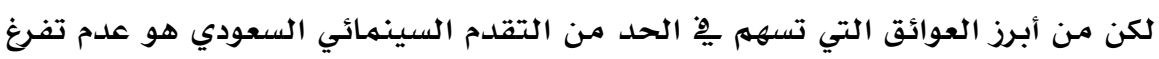

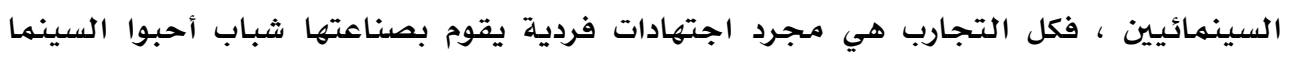
واجتهدوا لتقديم أفكارهم ورؤيتهم.

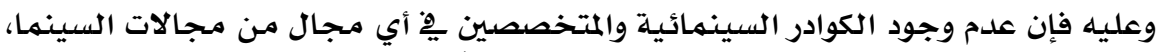

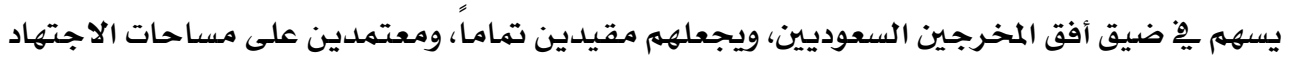
والابتكار.

الإعلام:

إن الانفتاح الكبير الذي عاشه القرن الواحد والعشرين والذي كان استمراراً للقرن

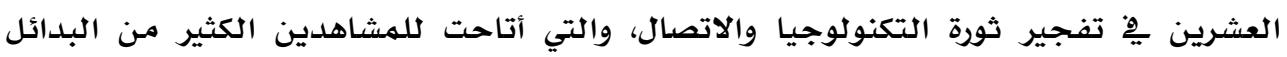

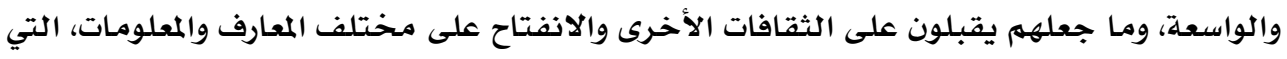

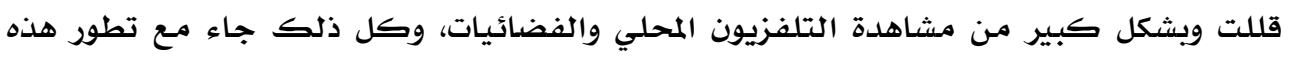

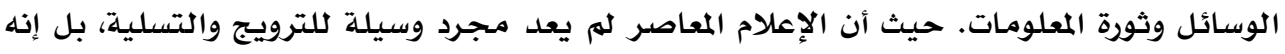

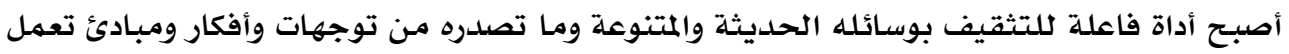
على إحداث تغيير كبير على أفراد المجتمـع وأفكارهم.

وإن كافة أوجه النشاط الاتصالية التي تستهدف تزويد الجمهور بكافة الحقائق والأخبار

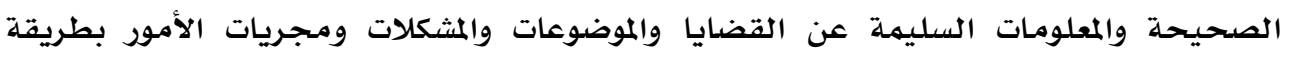

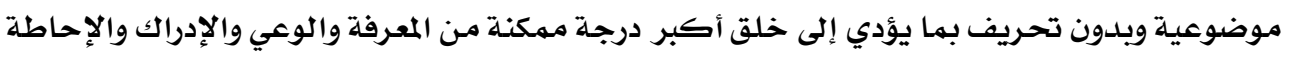

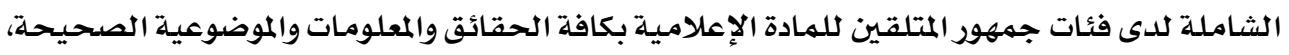

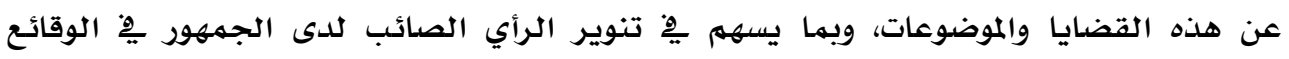

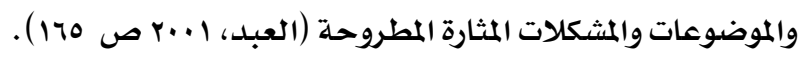
كما أن ما تقدمه تكنولوجيا الإتصال عن طريق الإعلام المعاصر قد أصبح من الركائز

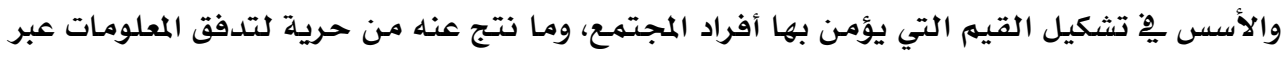

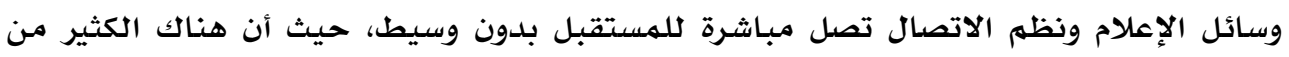

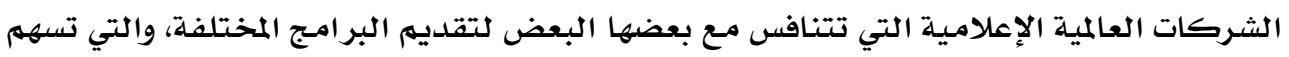

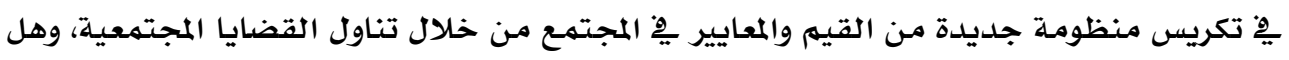

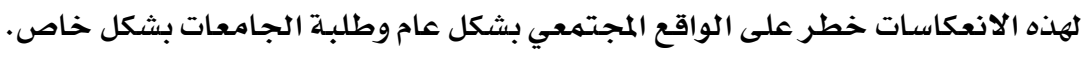
ومـع التغير الحاصل ِِّ مفهوم الإعلام وطبيعته ِِّ عصر العولمة، فقد تعددت وسائل الإعلام والاتصال الجماهيري، وأصبح الإعلام هو القوة الفاعلة ِِّ تشكيل العلاقات الإنسانية المختلفة، 


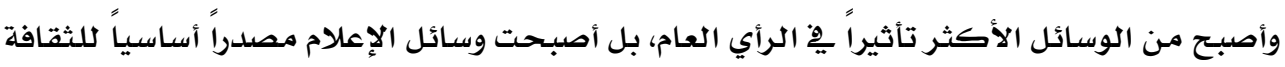

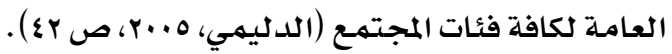
إن وسائل الإعلام الجماهيرية بجميع أشكا لها، صحافة كانت أم إذاعة أو تلفزيون أو سينما

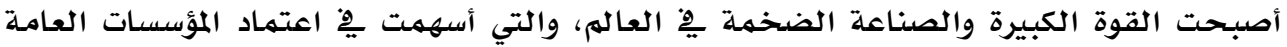

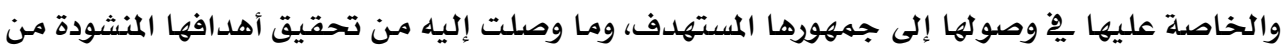

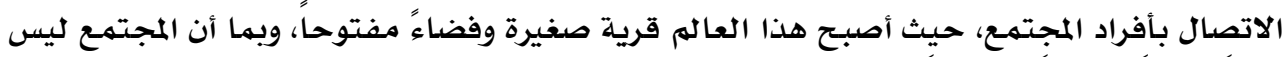

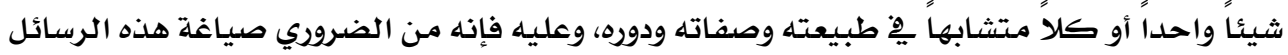

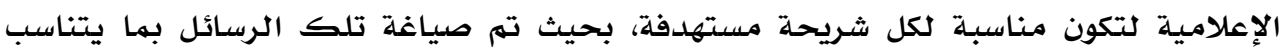

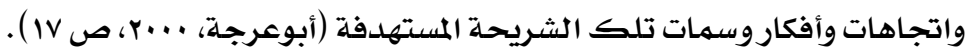

إن ما تعيث فيه المجتمعات البشرية بما فرضته عليها معظم معطيات العصر التقنية من

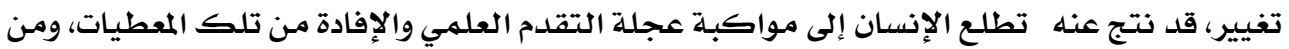

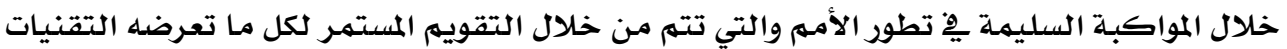

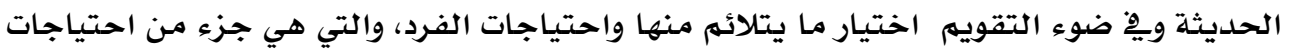

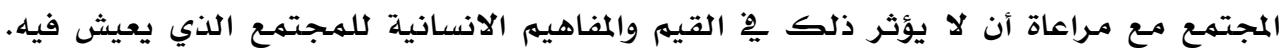

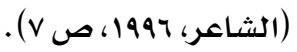

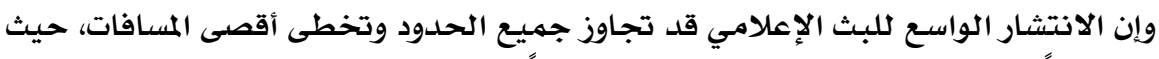

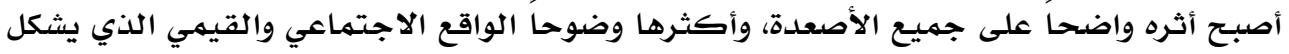

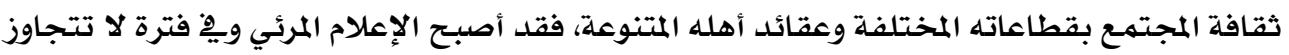

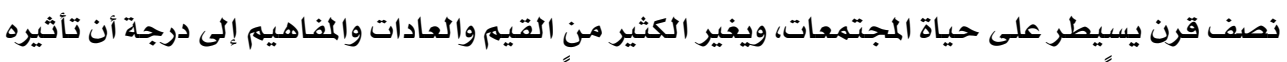

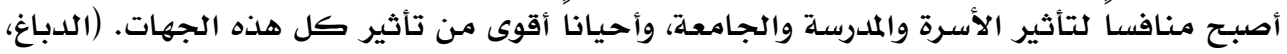
(₹) (1) (1994

ويعد الفيله القصير وسيلة تثقيية واعلامية تجمع بين فنون الاعلام والترويج للافكار و

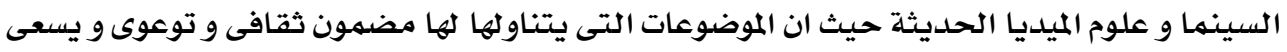

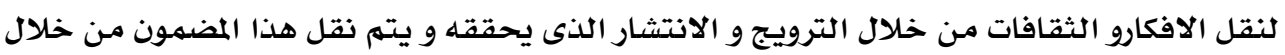

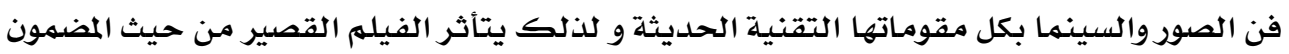

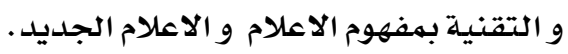
تعريف الإعلام الجلديلد: لا بـ من الاعتراف هنا بصعوبة تقديم تعريف محدد للإعلام الجديد، فعلى الرغم من ثرائه

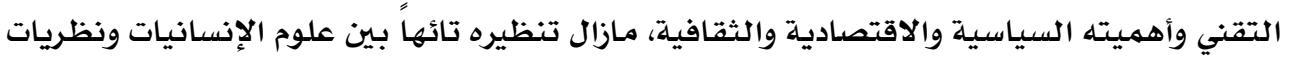

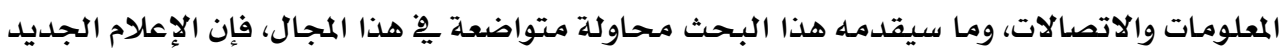

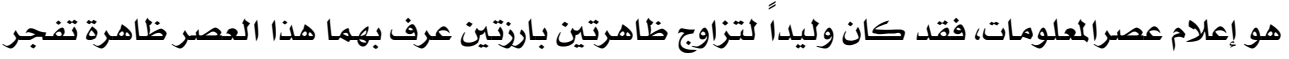

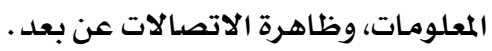


إن الإعلام الجديد يعتمد على استخدام الكمبيوتر والاتصالات عن بعد ـِّ إنتاج المعلومات

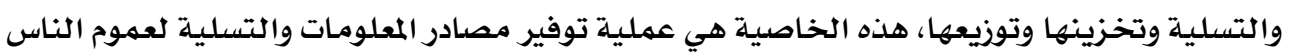

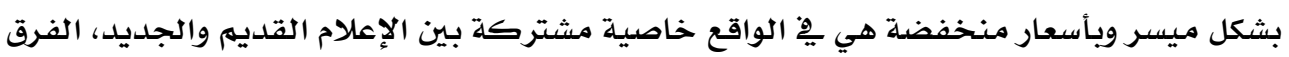

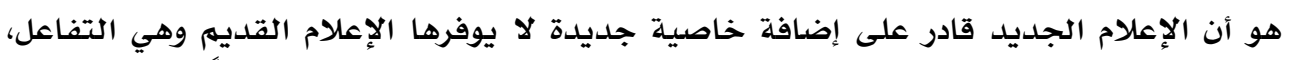

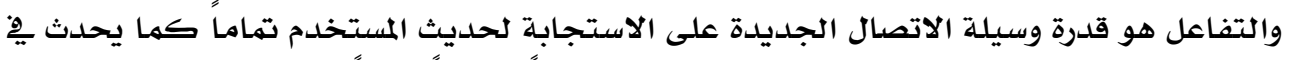

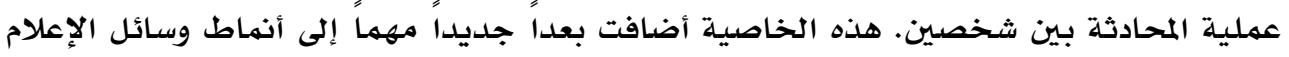

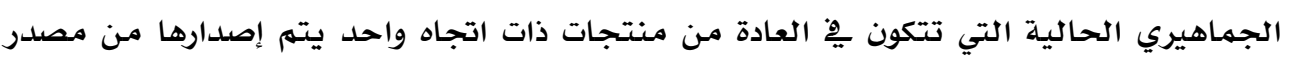

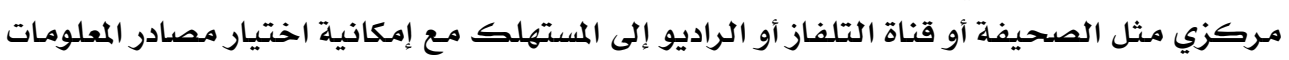
والتسلية متى أرادها وبالشكل الديفة أنيناة الثيلفاز أويده.

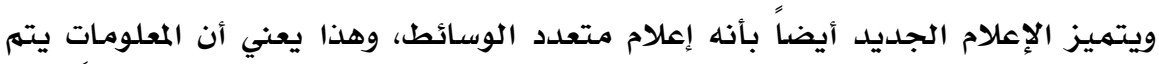

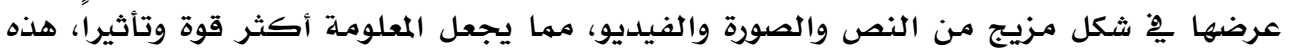

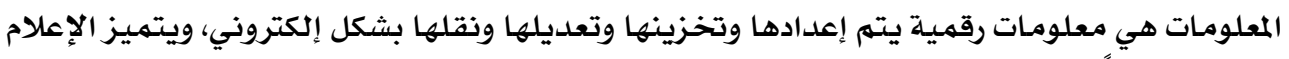

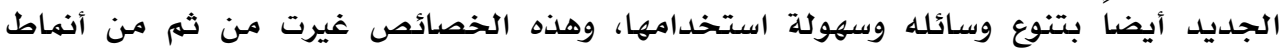

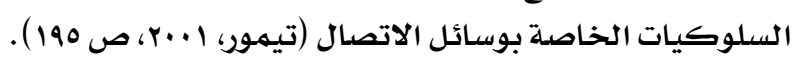

\section{العوامل الرئيسية للإعلام الجلديل}

وراء ظاهرة الإعلام الجديد عوامل تقنية واقتصادية وسياسية يهكن تلخيصها فيما يأتي:

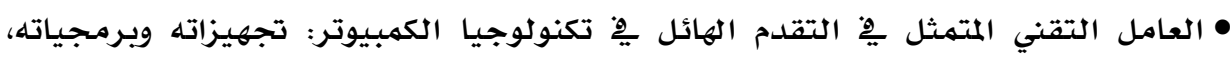

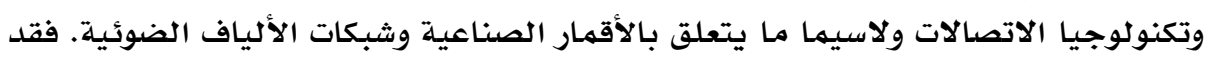

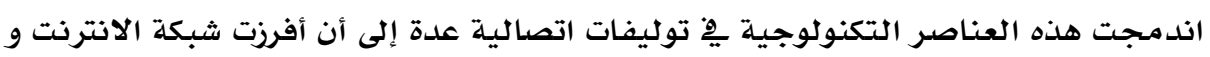

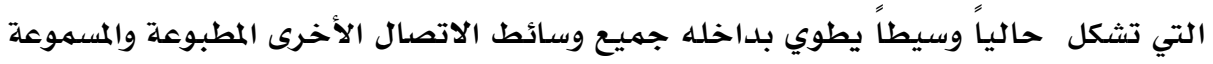

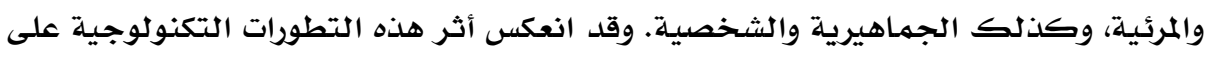

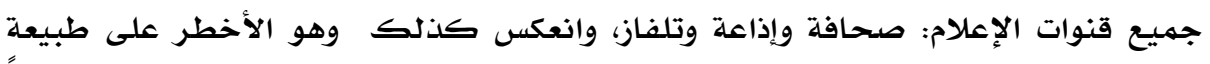

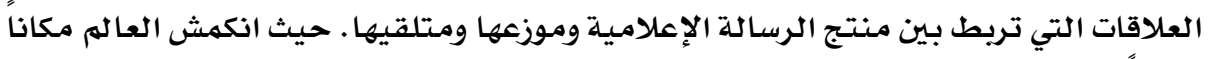

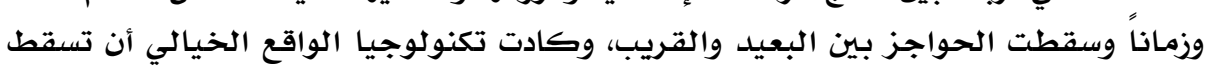

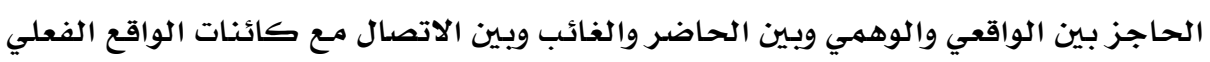

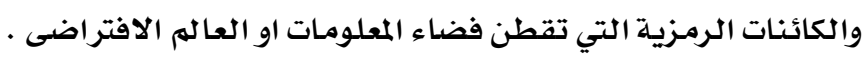

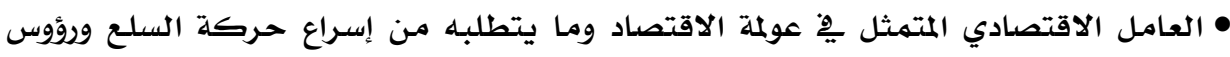

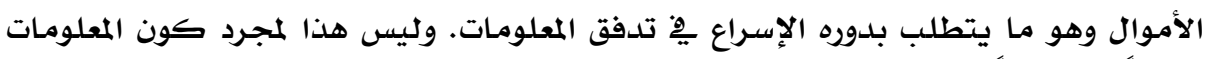

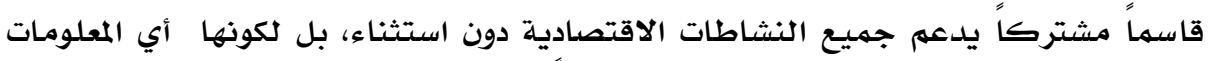

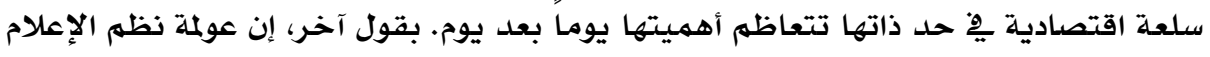

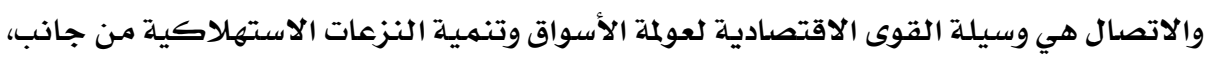

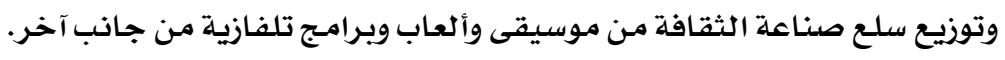


• العامل السياسي المتمثل بِ الاستخدام المتزايد لوسائل الإعلام من قبل القوى السياسية بهدف

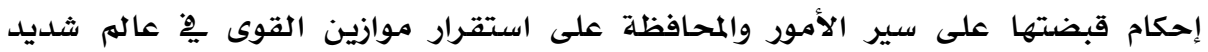

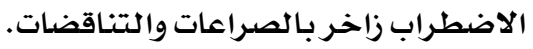

وقد تداخلت هذه العوامل التقنية والاقتصادية والسياسية بصورة غير مسبوقة، جاعلة من

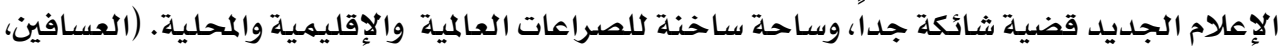

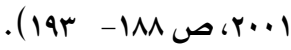

\section{سمات الإعلام الجديل:}

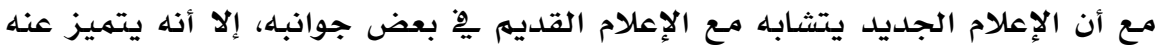

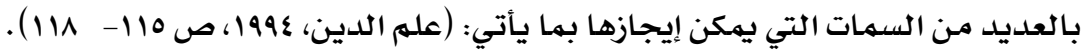

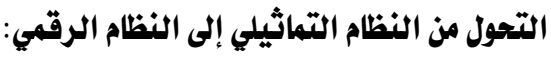

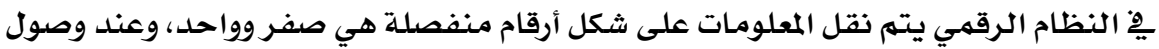

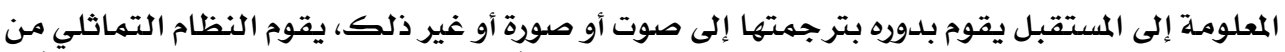

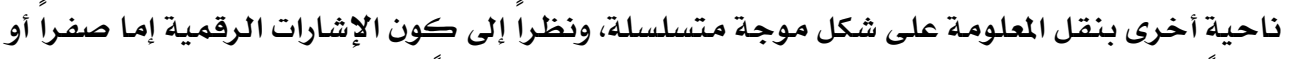

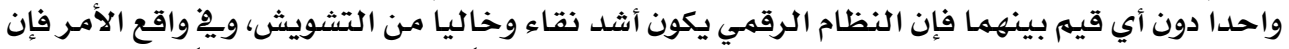

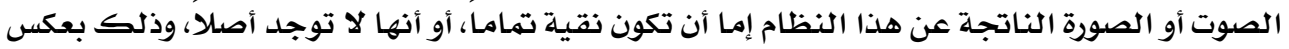

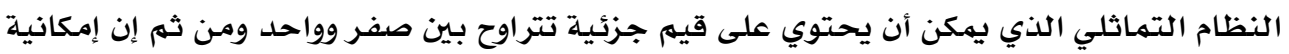

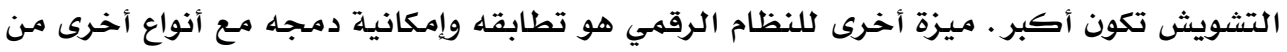

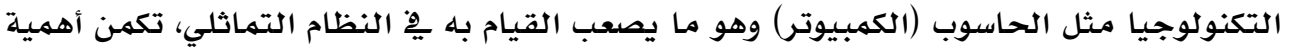

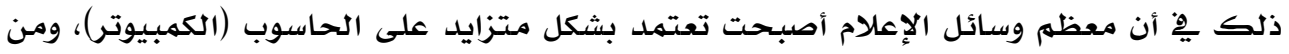

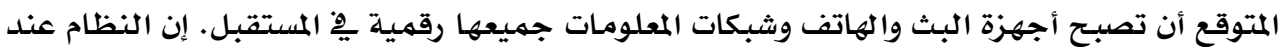

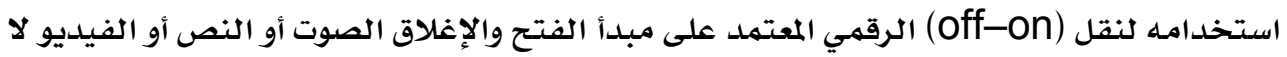

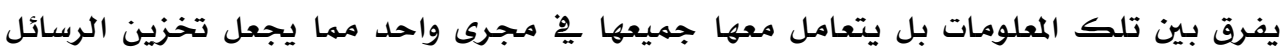

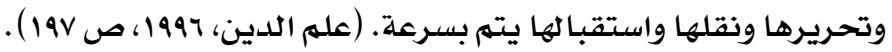

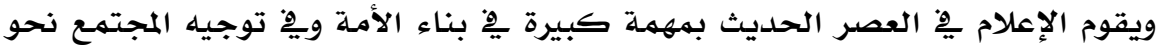

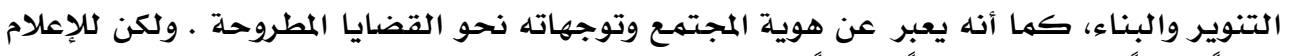

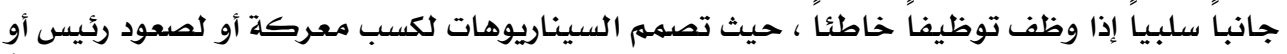

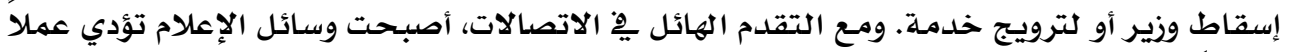

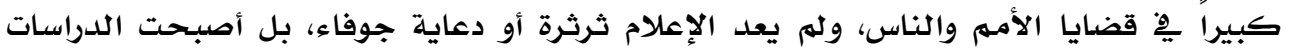

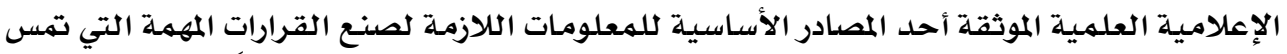

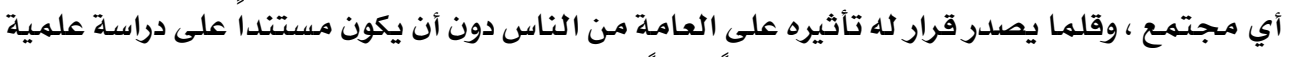

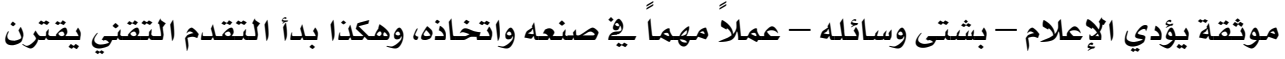

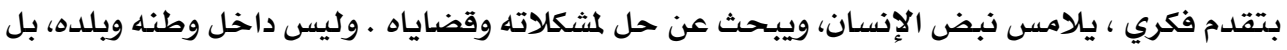


أيضاً داخل الكرة الأرضية التي أصبحت بفضل ثورة الاتصالات المذهلة والفضائيات المنتشرة والإنترنت

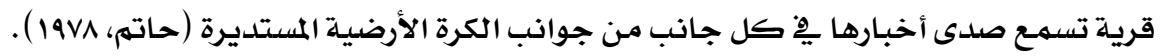
ويطلق الكثير من العلماء على العصر الذي نعيشه عصر (ثورة الاتصالات والمعلومات) . وهذاته

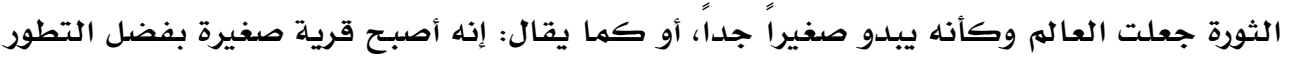

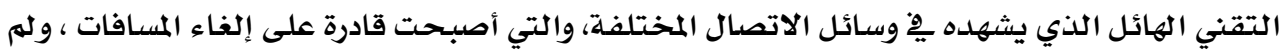

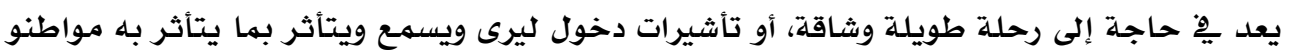

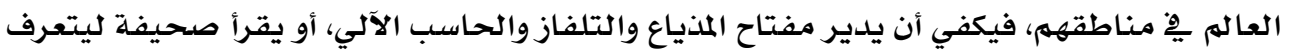

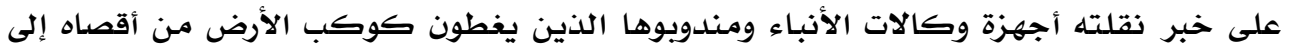

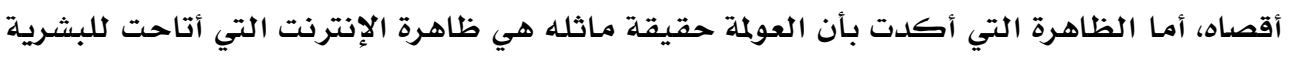

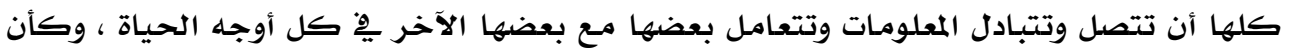

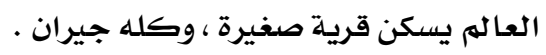

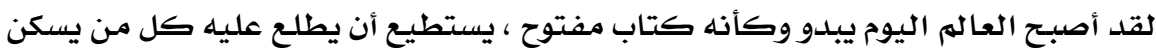

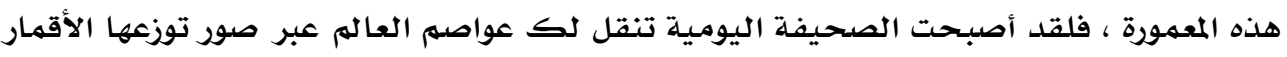

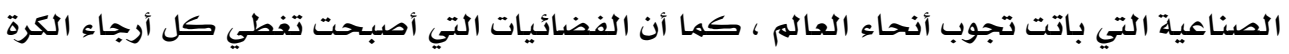

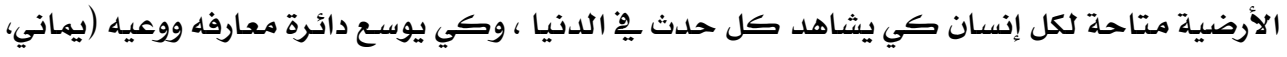

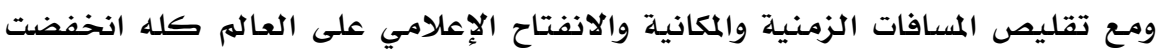

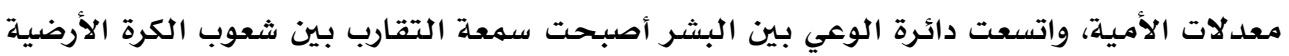

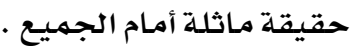

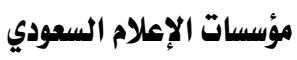

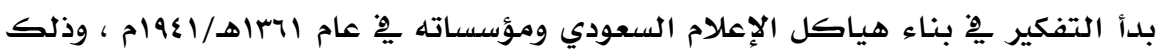

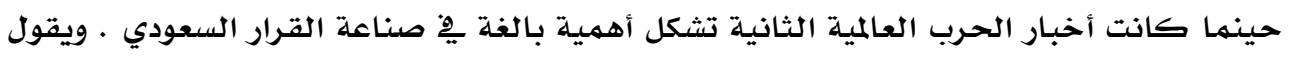

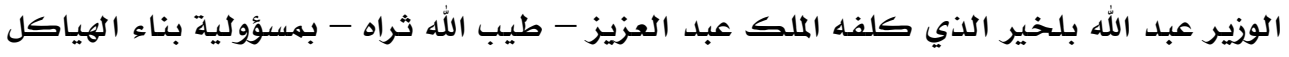

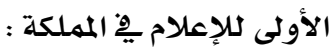

بعد سقوط باريس الساهـ / ا§وام أثناء الحرب الكونية الثانية ، حيث سحبت الحكومـة

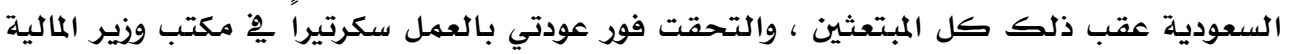

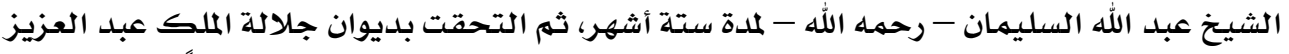

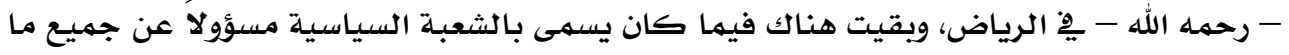

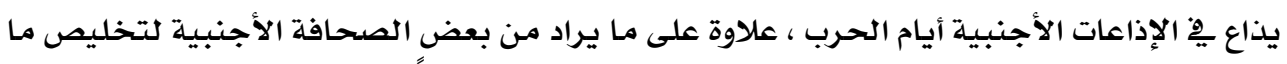

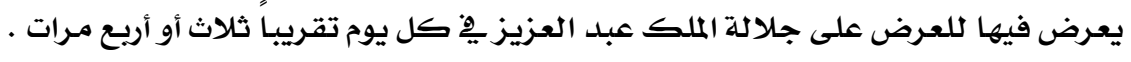

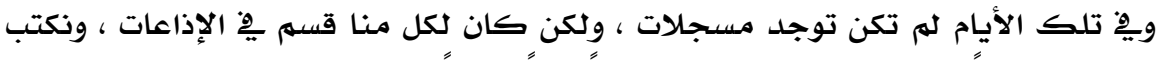

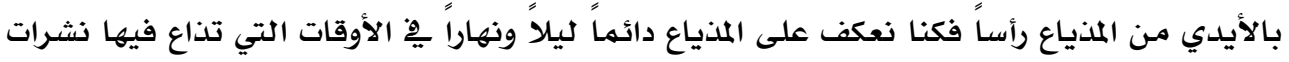


الأخبار بقدر الإمكان وبالتهرين ، أصبـحنا نلاحق كل ما يذاع بنسبسة ـ9٪ ، وبقيت ِِّ هذه الوظيفة

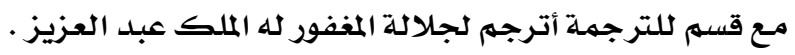
ولقد كانت الإذاعة يِّ بدايتها تحت إدارة وزارة المالية وسلطتها ، على حين كانت الصحافة

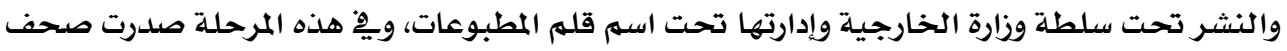

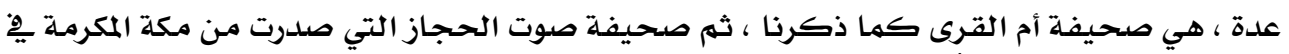

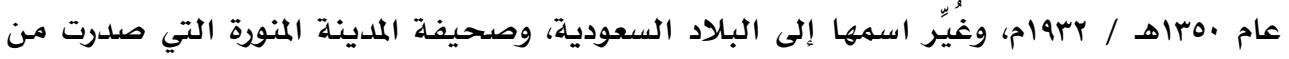

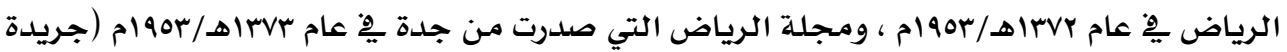

المدينة المنورة)

ولكن يِّ عام عVIاهـ / بهوام كان التاريخ الحقيقي لإنشاء الجهاز التنظيهي الإعلامي

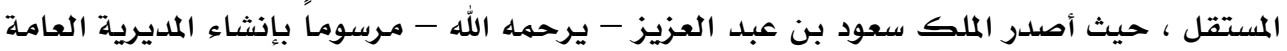

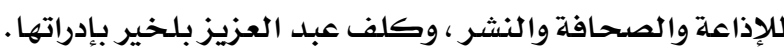
ولقد لخص المرسوم الملكي الذي صدر بإنشاء المديرية العامة للإذاعة والصحافة والنشر بأن

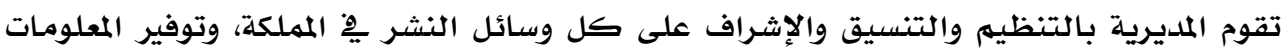

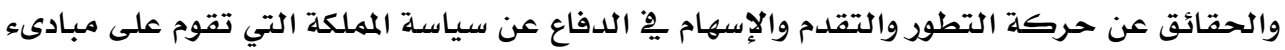

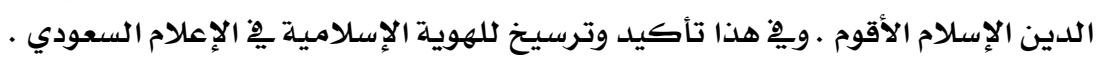

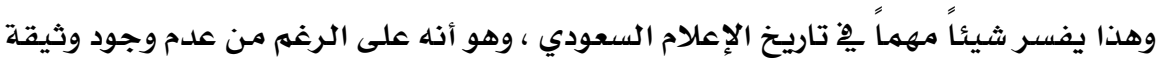

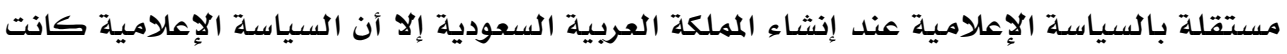

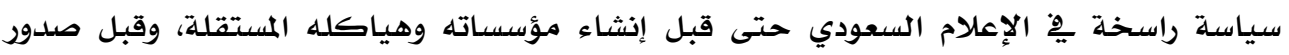

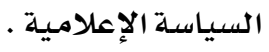

بمعنى أن الهوية الإسلامية هي سياسة عامـة ثابتة وراسخة تتفاعل مـع الخريطة السياسية

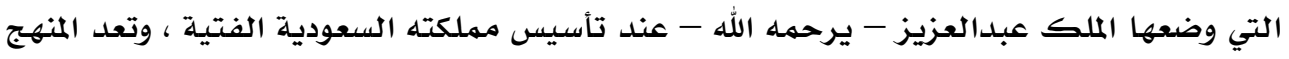

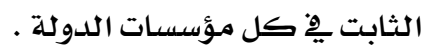

ولقد أنشيء أول جهاز إعلامي تحت اسم المديرية العامـة للإذاعة والصحافة والنشر

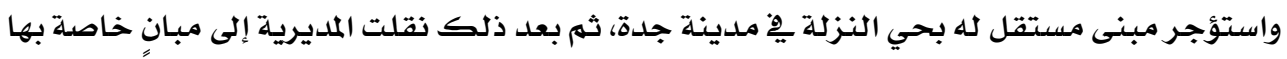

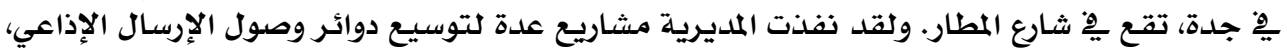

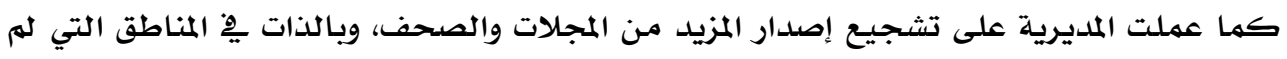

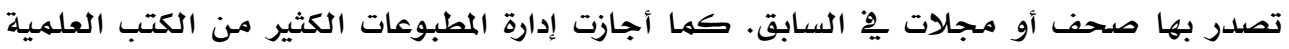
والإعلامية (جريدة أم القرى).

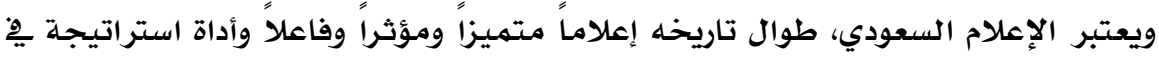

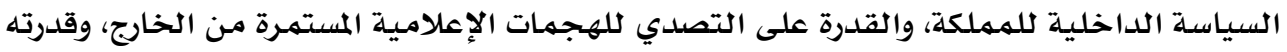

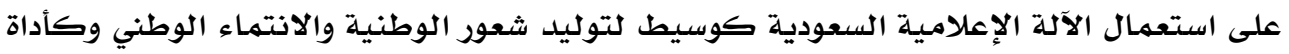

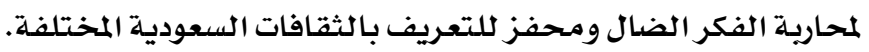


والباحث ِِّ مسيرة الإعلام السعودي يخرج بنتيجة مؤداها أن الأداء المهني لوسائل الإعلام

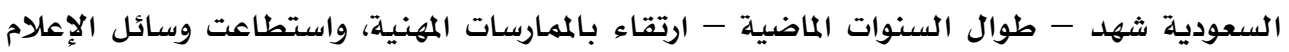

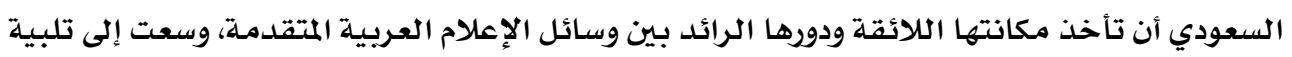

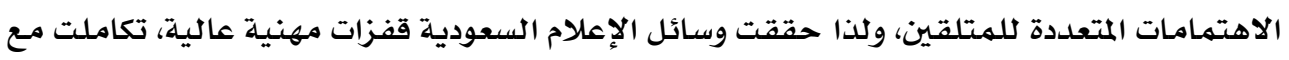

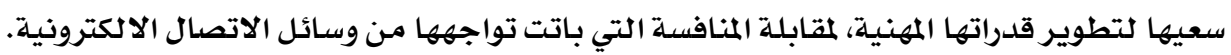

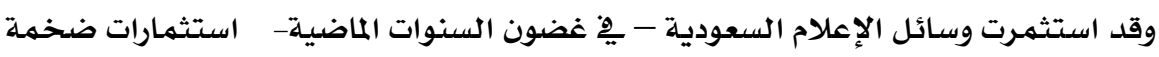

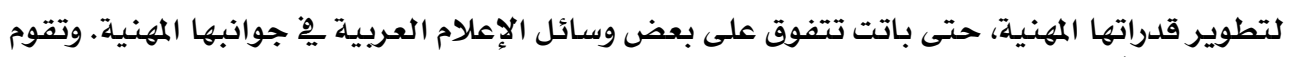

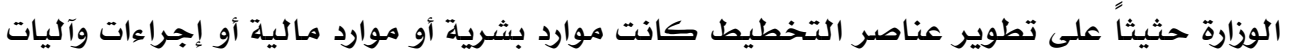
تنفيذية وتشغيلية بما يناسب تطلعات الوزارة المستقبلية. وتسعى وسائل الإعلام السعودية لإحداث تغييرات شاملة وعميقة خاصدة بالنسبة للإعلام

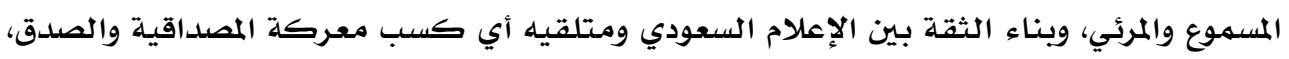

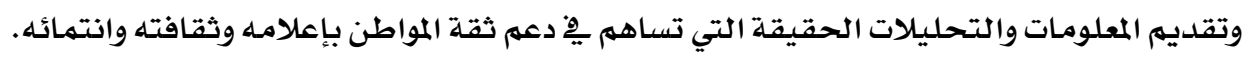

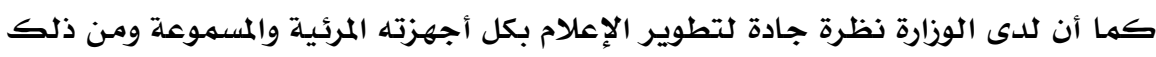

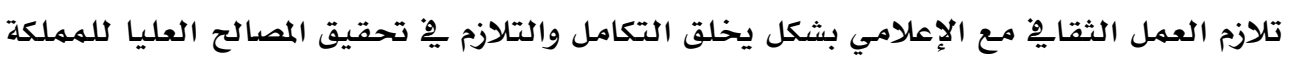

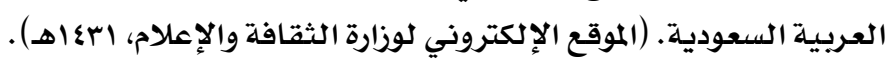

\section{الدراسات السابقة}

اطلعت الباحثة على عدد من الدراسات المحلية والعربية والأجنبية ذات الصلة بالموضوع

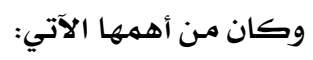

أولاً: الدراسات العربية

• دراسة محمد، عزة عبد العظيم، (..... بعنوان: تأثير الدراما التلفزيونية على إدراك الواقع

الاجتماعي كلأسرة المصرية.

هدفت الدراسلة إلى التعرف على العلاقة بين التعرض للدراما العربية التلفزيونية التي

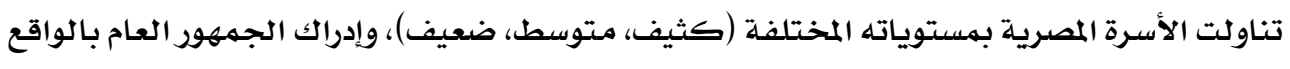

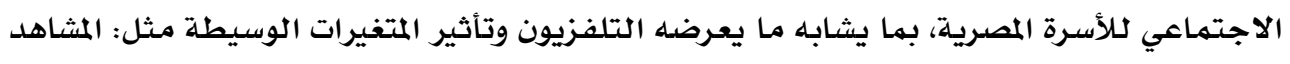

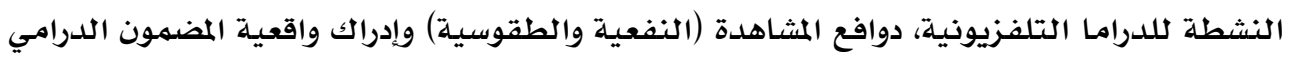

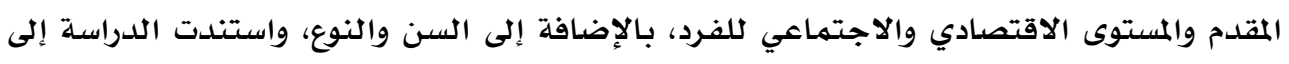

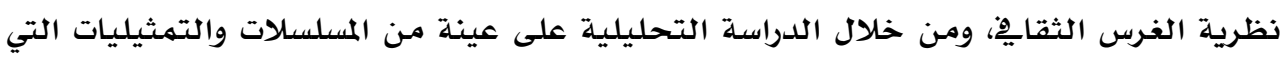

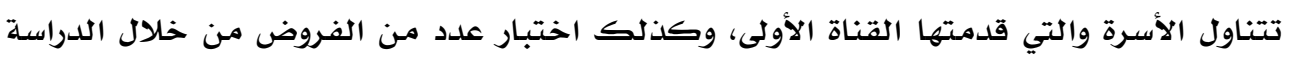

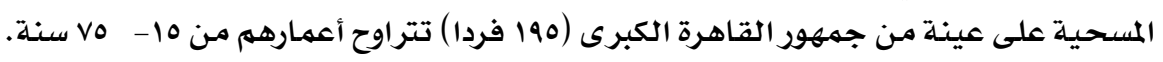
وتوصلت الدراسة الميدانية إلى عدة نتائج منها: 


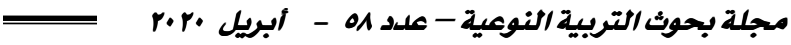

ا . عدم وجود علاقة بين كثافة مشاهدة الدراما التلفزيونية وإدراك الجمهور للواقع الاجتماعي

$$
\text { لنلأسرة المصرية. }
$$

r. أن هناك أريعة دوافع أساسية لمشاهدة الدراما التلفزيونية وهي التعله، التعود، التسلية،

$$
\text { والتفاعل مـع الآخرين. }
$$

• دراسة معوض، محمد، وعبد الجليل، عبد الباسط، (..... بعنوان: علاقة شباب دولة الكويت

بالقنوات الفضائية.

تهت الدراسـة على عينة قوامها ( ... مفردة مـن طلبة جامعة الكويت المشاهدين للمحطات

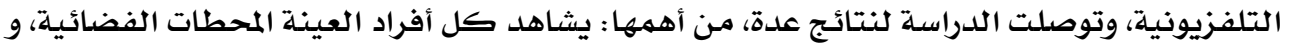

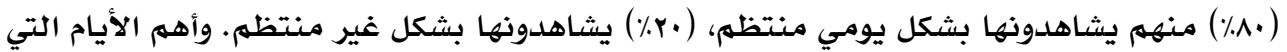

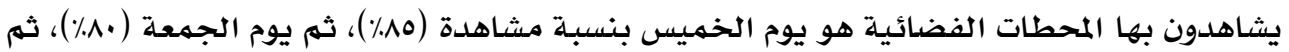
يوم الأريعاء (vo٪).

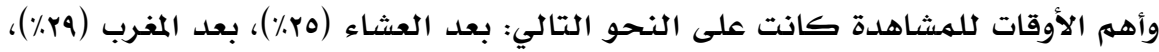

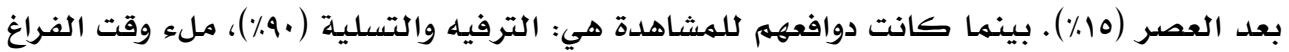

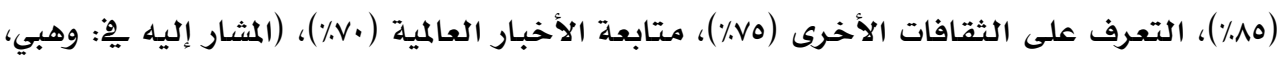

• دراسة، عبيدات، ذوقان عبد الله (r..r.) بعنوان: الفضائيات والانترنت: معالجة السلبيات للى الناشئة تعزيزا للإيجابيات.

هدفت الدراسة لمعرفة ما يشاهده الطلبة يِّ عدد من دول الخليج العربي عبر شاشات

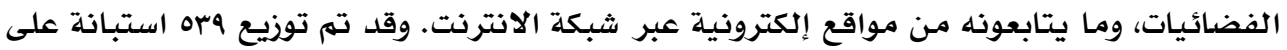

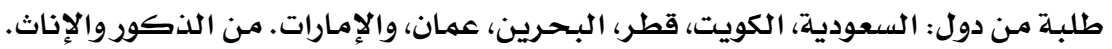

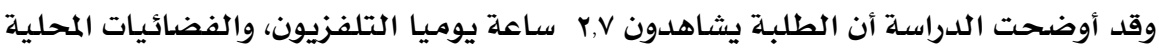

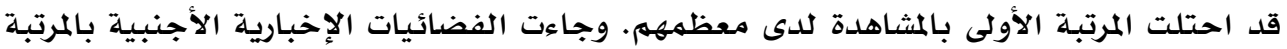
الأولى لمعظم الطلبة يِّ كونها مصدر حصولهم على الأخبار تليها الفضائيات المحلية ثم العربية.

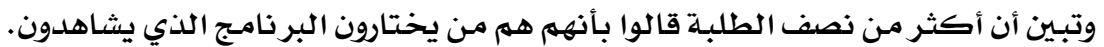
بينها يتفاوت من دولة لأخرى امتلاك الطلبة لجهاز تلفزيون خاص داخل غرفهم، لكن

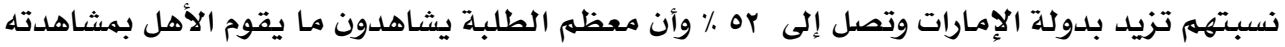
من برامج تلفزيونية.

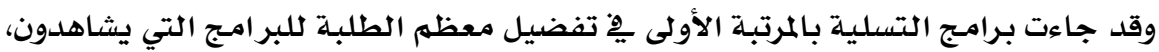

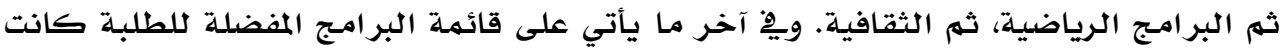
البر امـج السياسيـة. 
• دراسة اللحياني (^••r) بعنوان: أثر الفضائيات على المراهقين والمراهقات فِ المملكة العربية السعودية من وجهة نظر التربويين والتربويات.

هدفت هذه الدراسة إلى التعرف على أهم الخصائص العالمية للفضائيات من وجهة نظر

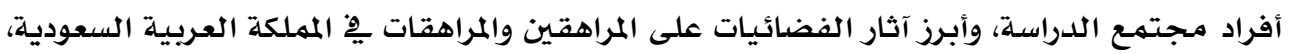

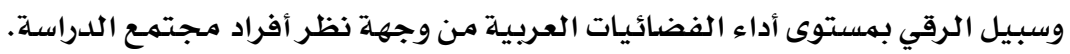

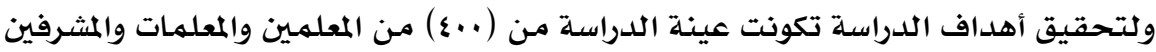

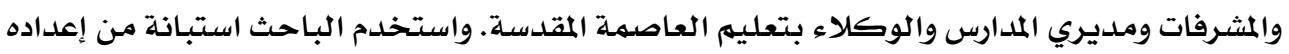

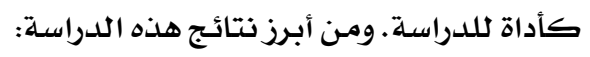
ا ـ أن هناك خصائص إعلامية تتميز بها الفضائيات مما أدى إلى جذب فئلة المراهقين من الجنسين نحو الإقبال على مشاهدتها. r . أن أفراد عينة الدراسة يوافقون أن هناك آثار إيجابية للفضائيات.

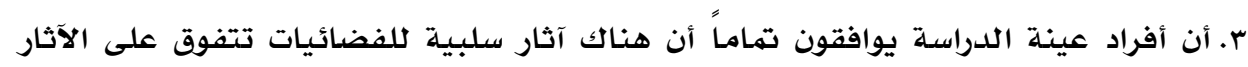

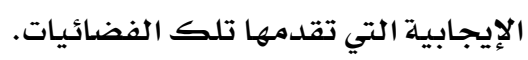
ع. أن أفراد عينة الدراسـة يوافقون على وجود سبيل لتطوير أداء الفضائيات والرقي بما تقدمها مـن برامـج تخاطب فئة المراهقين من الجنسين. ه. وجود فروق ذات دلالة إحصائية بين أفراد عينة الدراسة بالنسبة لأبرز آثار الفضائيات لصالح المعلمـين والمعلمات. • دراسة فدوى ياقوت (11 ·rم ) بعنوان: أسئلة البناء يِ سيناريو الفيلم الروائي القصير. و هى دراسـة نظرية استعرض فيها تاريخ و اصول الافلام القصيرة و اوضحت الفروق بين

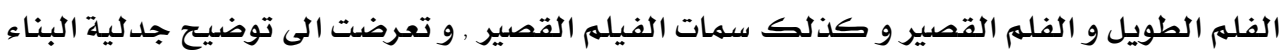

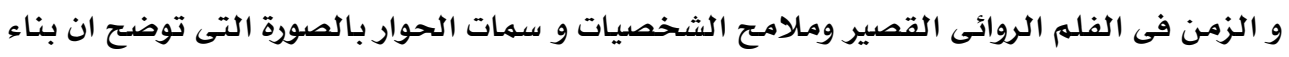

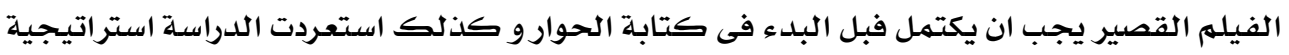

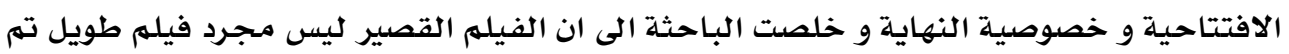

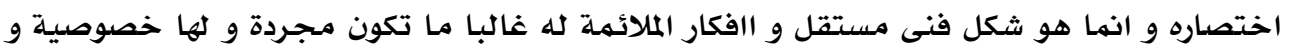

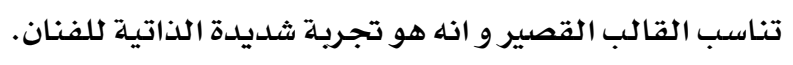

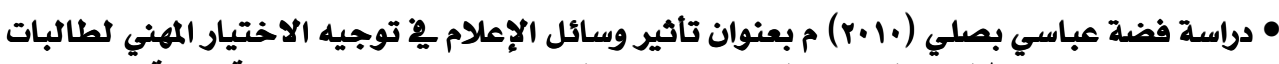

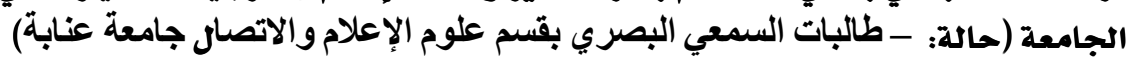
هدفت هذه الدراسة إلى إبراز الدور الذى يؤديه وسائل الإعلام في توجيه الاختيار المهني 


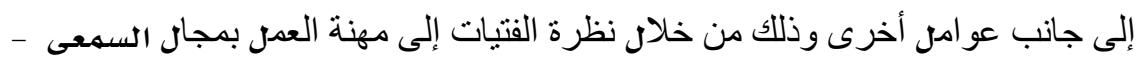

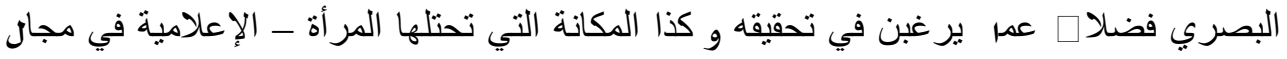
السمعي البصري من وجهة نظر هن.

وتوصلت الدراسة إلى تأثير وسائل الإعلام بالدرجة الأولى في الاختيار المهنى للطالبات و

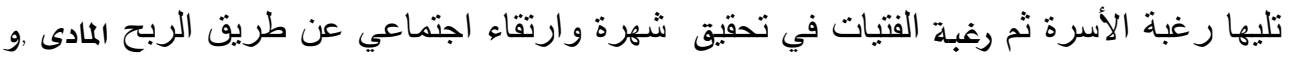

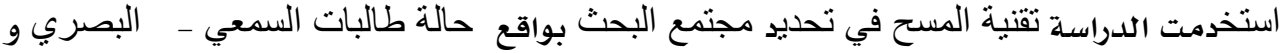

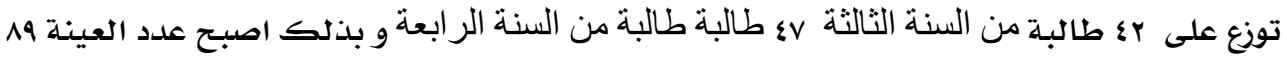
من اصل مror طالبة يدرسن بقسم علوم علوم الاعلام و الاتصال

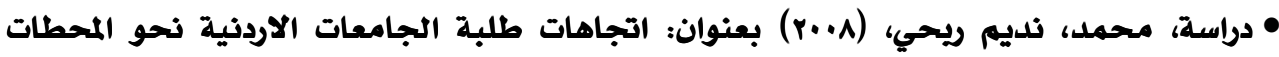
الفضائية العربية.

هدفت هذه الدراسة إلى التعرف على اتجاهات طلبة الجامعات الأردنية نحو المحطات

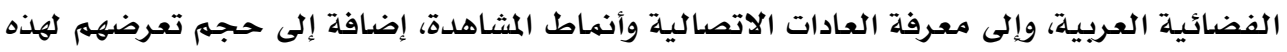

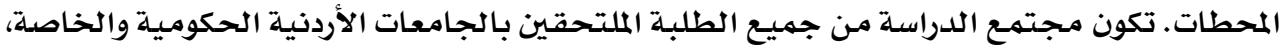

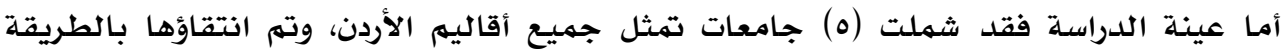

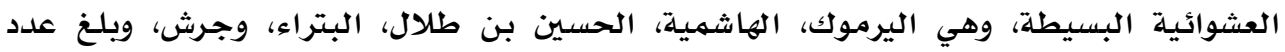

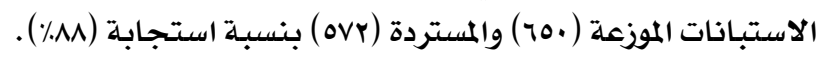

$$
\text { وتلخصت أبرز النتائج التي توصلت لها الدراسـة فيما يلي: }
$$

ا. جاءت محطة (YMBC) الأكثر مشاهدة من قبل الطلبة من بين جميع المحطات العربية

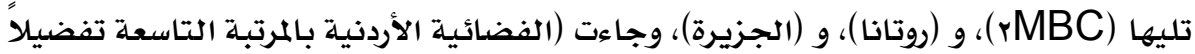

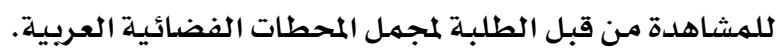

r · جاءت المحطات الفضائية العربية التالية الأدنى مشاهدة من قبل الطلبة: (الفضائية المصرية)،

$$
\text { (العقاريـة)، و (الاقتصادية). }
$$

r. اتفق معظم الطلبة على أن الكليبات الغنائية التي تبث عبر المحطات الغنائية العربية فاضحة

$$
\text { وخادشة للحياء العام ولا تراعي الآداب. }
$$

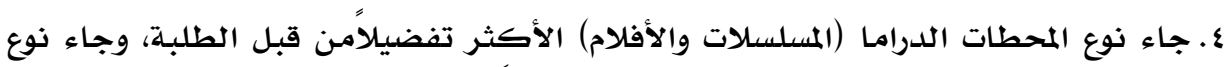

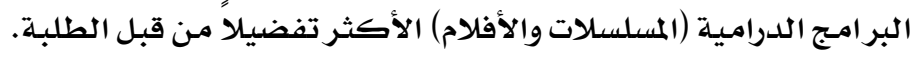

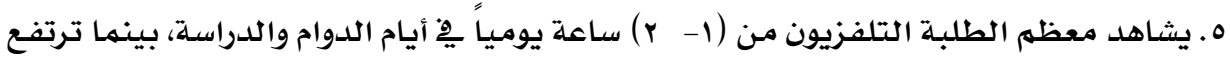

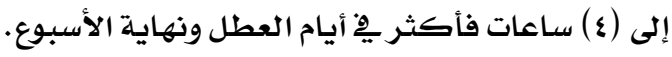
7. فترة السهرة من (^- 11 ) مساءا هي الأكثر مشاهدة لدى الطلبة، والهدف الأبرز من المشاهدة هو الترفيه والتسلية، ثم قتل الفراغ والملل. 
V. يجد معظم الطلبـة المحطات الدينية تزيد من صلتهم من الله، وتشدهم محاضراتها وبرامجها

$$
\text { للمتابعة. }
$$

1. وخلصت الدراسـة لمجموعة من التوصيات من أهمها:

9. زيادة حصة الشباب يِّ برامـج التلفزيون.

$$
\text { •l الاهتمام بالإنتاج الدرامي العربي. }
$$

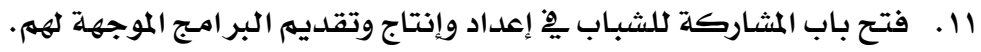
r ا. الابتعاد عما يخدش الحياء العام والآداب يِّ الكليبات الغنائية التي تبثها المحطات الغنائية.

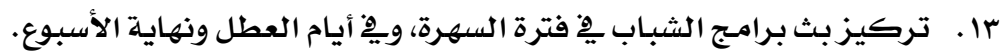
ع ا. تقديهم برامـج موجهة للشباب تنهض بهم ثقافياً ومعرفياً، وتزودهم بالعلهم والتسلية الهادفة.

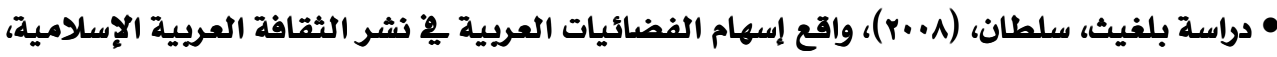

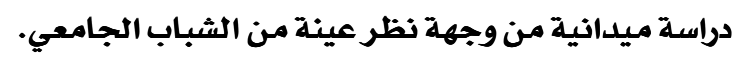

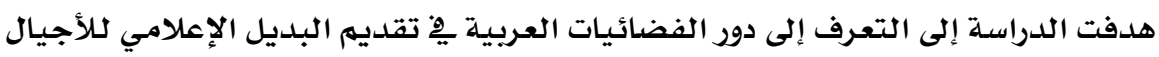

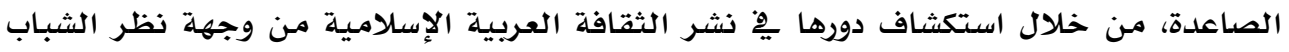

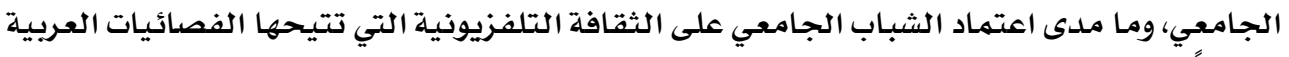
مصدرا للمعرفة والثقافة الإسلاميلة.

بينت نتائج الدراسة أن البث المباشر ساهم مِّ خلق واقع إعلامي جديد على الصعيد الكوني،

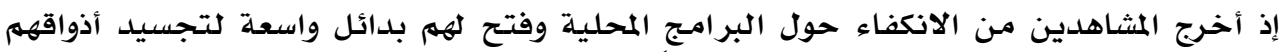

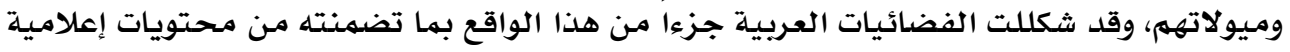

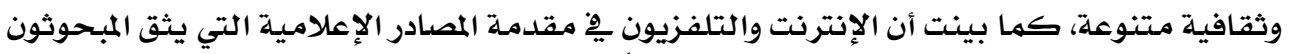

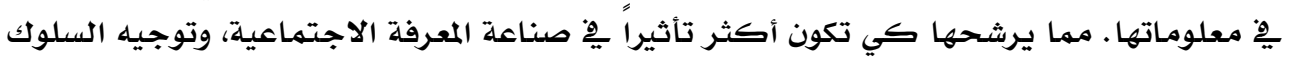

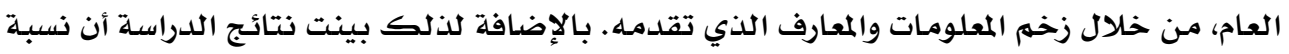

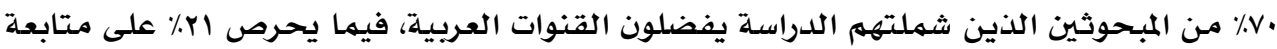

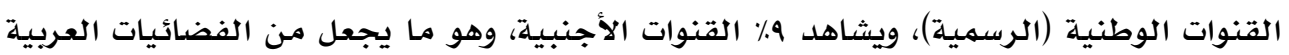

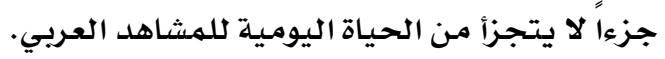

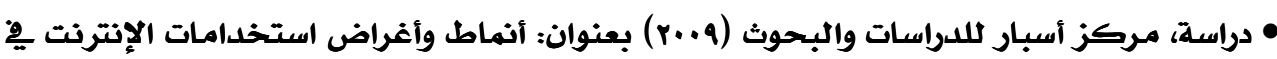
المجتمع السعودي.

غطت هذه الدراسـة جميع مناطق المملكة، حيث شملت: منطقة الرياض، المنطقة الغربية،

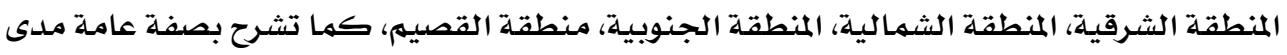

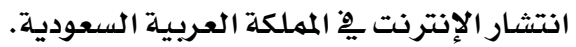
وأشارت نتائج الدراسة إلى أن أكثر من vr٪ من مستخدمي الإنترنت يقضون أكثر من

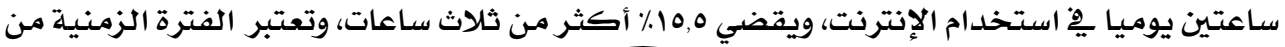




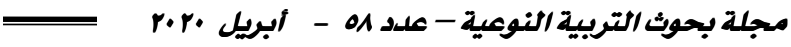

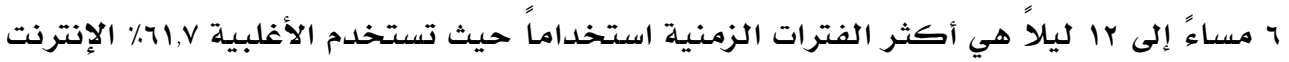
خلال تلك الفترة.

ثانياً: الدراسات الأجنبية

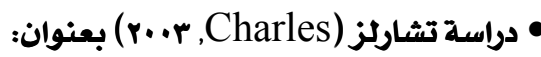

The Quality of television program content and its relationship to the achievement and behavior in late-Latency age student

هدفت الدراسـة إلى التعرف على نوعية البرامج التلفزيونية وعلاقتها بإنجاز وتصرف التهاف

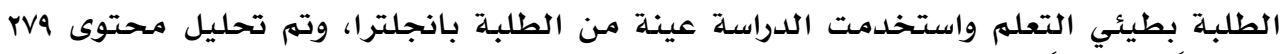

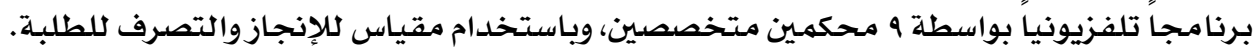
وقد بينت نتائج هذه الدراسة أن برامجج التلفزيون تقدم راحة غير واقعية للمشاهدين، وإن

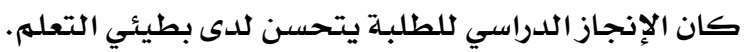

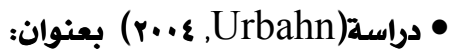

Reporting the Truth: Media Perceptions, Preferences, and Practices among Young UAE Nationals

تم يٌْ هذه الدراسـة التي قام بها باحث أمريكي مختص بالإعلام لصالح السفارة الأمريكية بأبوظبي استطلاع آراء مجموعة من الشباب من جامعـة الإمارات المتحدة، وغي حول القنوات

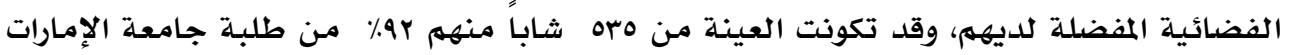
بمدينة العين.

وقد توصلت الدراسـة إلى أن أكثر المحطات الترفيهية تفضيلاً كانت أبو ظبي الفضائية

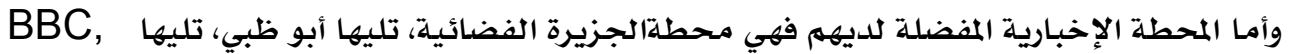

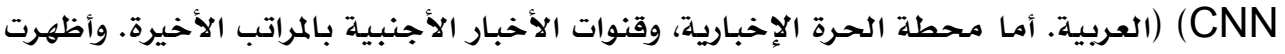

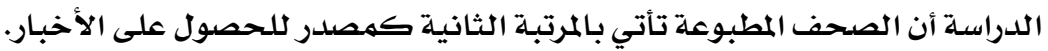

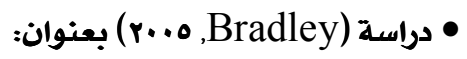

Media-Use Study Finds Youths Increasingly Multi-Tasking.

كشفت هذه الدراسـة " دراسة لاستخدام الوسائل الإعلامية" إلى أن الشباب يقومون بعدة

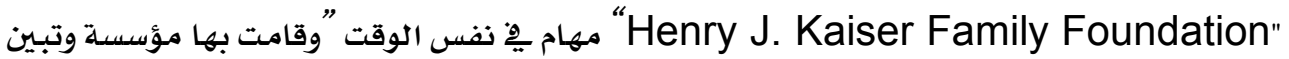
أن الشباب يقضون جزءا كبيرا مُن وقتهم مِّ التعامل مـع أشكال متعددة من الوسائل الإعلامية.

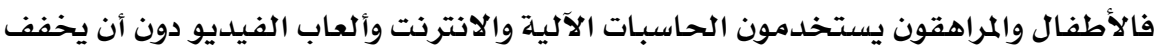

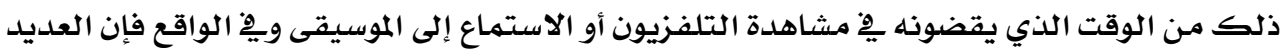

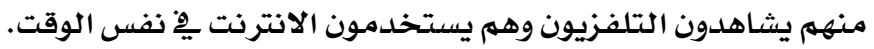




$$
\begin{aligned}
& \text { = ب داسة الثرالأفلام/القصيرة على المجتمع السعودي } \\
& \text { • دراسة (Robison, ه . • ب) بعنوان: }
\end{aligned}
$$

\section{The Rest of Arab World}

خلصت هذه الدراسة إلى أن المشاهدين العرب للقنوات الفضائية يبحثون بالدرجة الأولى تلى

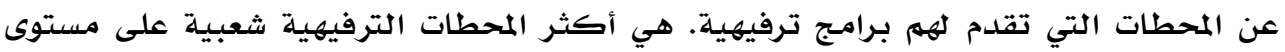

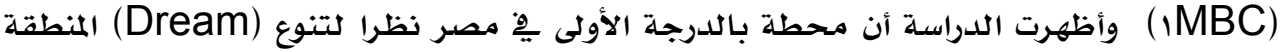

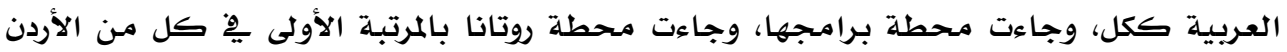

$$
\text { والسعودية. }
$$

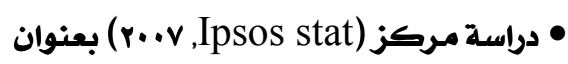

National Media Analysis (NMA) Jordan 2007 TV section

هدفت الدراسة إلى قياس عادات مشاهدة التلفزيون الأردني لتزويد شركات الإعلان بأوقات الذروة التي يكون فيها أعلى نسبة مشاهدة.

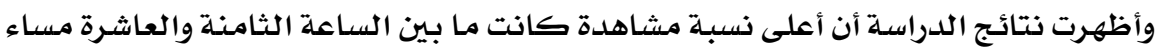

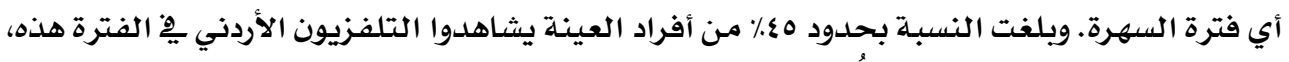
لمدة لا تقل عن خمس دقائق يومياً.

وكانت نسبة المشاهدة للذكور أعلى من الإناث ِِّ الفترة ما بين الساعة الثامنة والثانية

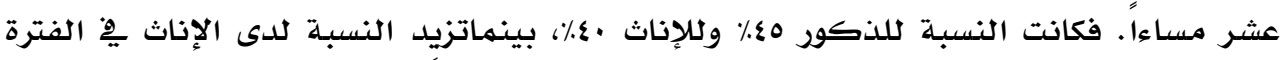

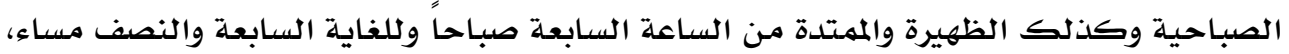

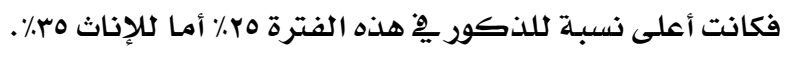

وبالنسبة لمتغير العمر، فكانت أعلى نسبة مشاهدة لأفراد العينة التي تزيد أعمارهم عن 0؛

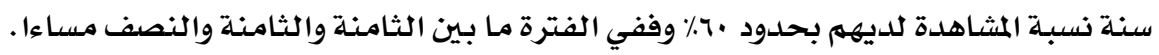

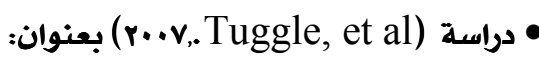

Reporting Live From the Scene: Enough to Attract the 18-24 Audience

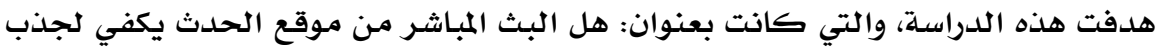

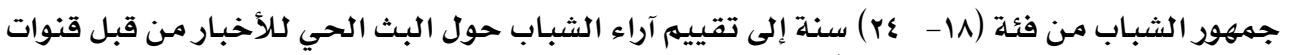

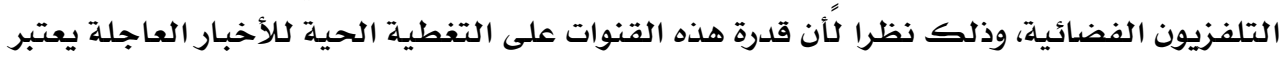
من أهم عناصر القوة التي لهم يسبق لها مثيل للتلفزيون.

وقد تم تصنيف المتغيرات التي أجاب عليها الشباب يِّ إحدى الطرق الثلاثة التالية مدى الثى

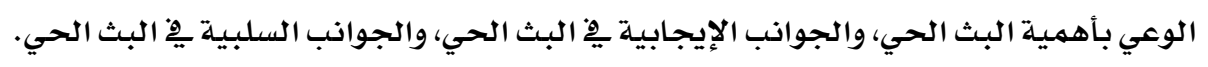

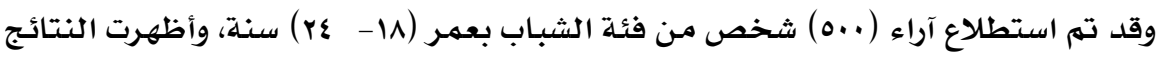

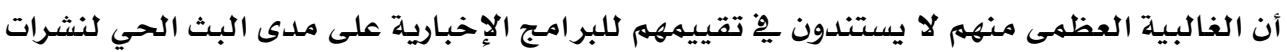
الأخبار فيها أو على كونها أولى المحطات التي تنشر الأخبار العاجلة مبلة مباشرة. 


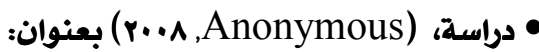

Favorite TV Channel Survey: Digital Satellite Channels.

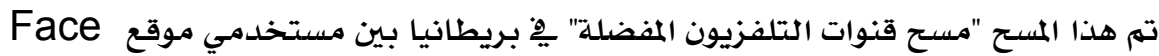

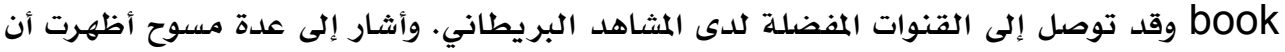

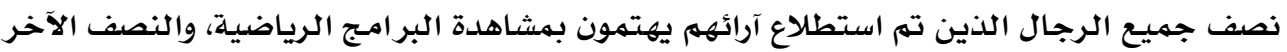

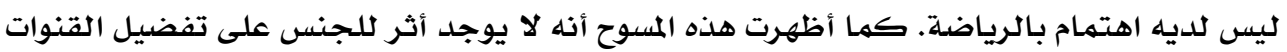

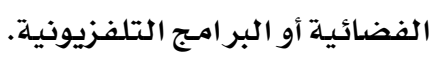

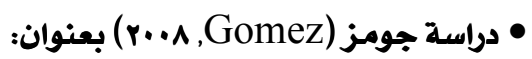

\section{Commercial, Television and students education in Mexico}

هدفت الدراسة إلى التعرف على أثر برامج التلفزيون التجاري على تحصيل وتعليم الطلبة

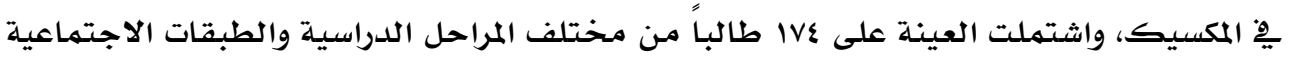

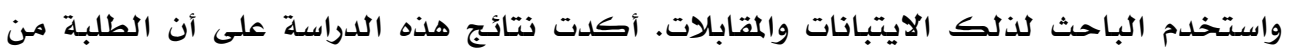

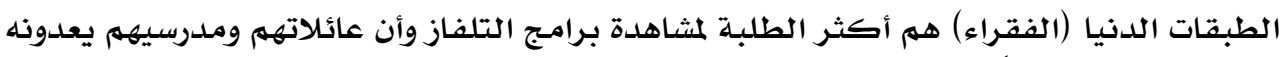

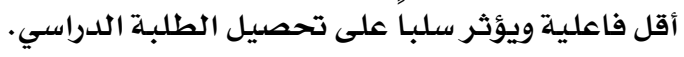

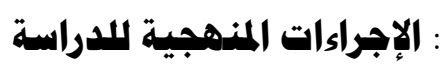

منهج الدراسة:

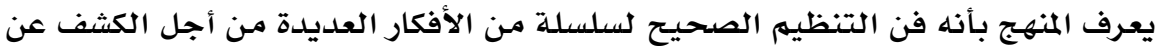

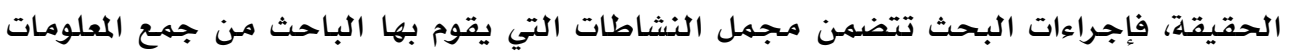

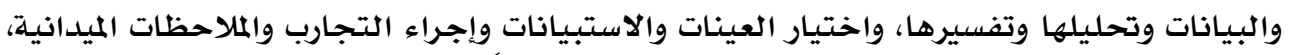

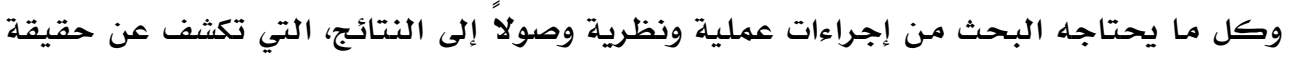

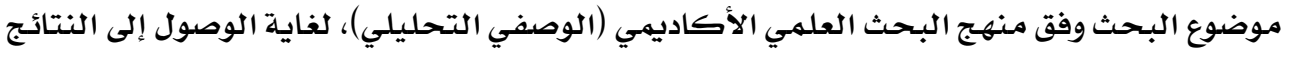

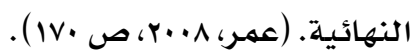

وبالنظر إلى طبيعة هذه الدراسـة والأهداف التي تتوخى تحقيقها والممثلة ِِّ دراسـة أثر

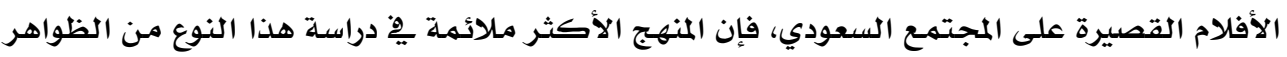

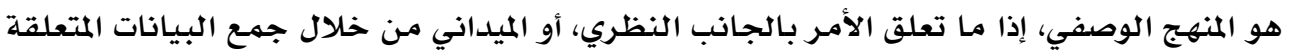

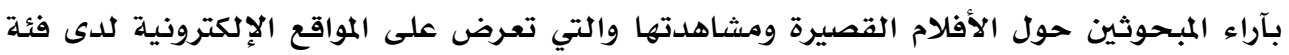

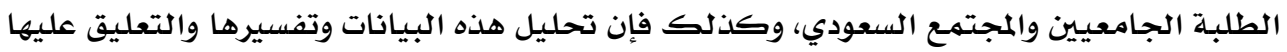

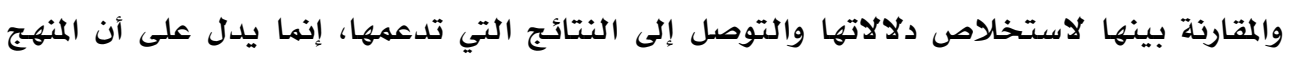

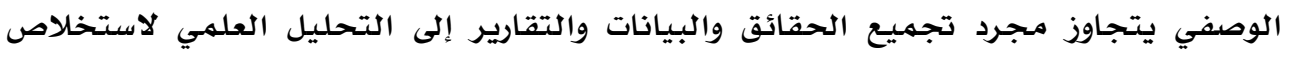

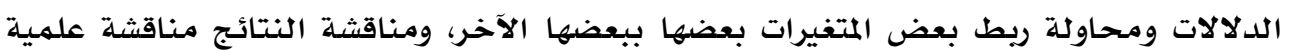
وتفسيرها يِّ عبارات واضحة، فهذا المنهج يتعدى الوصف والتقرير إلى التحليل والتفسير والريط بين 
المدلولات بغرض معاينة الظاهرة المدروسلة، والوصول إلى تصور مقترحات وتوصيات للتعاطي العلهي

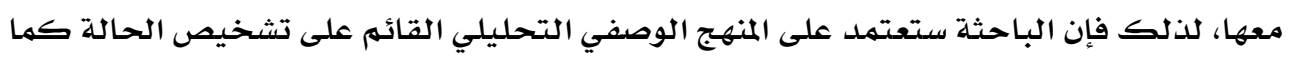

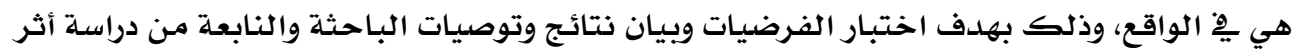
الأفلام القصيرة على المجتمع ودلف السعودي.

عينة الدراسة:

تم اختيار عينة عشوائية من طالبات كلية التصاميم والفنون بجامعة الأميرة نورة ، ثم قام

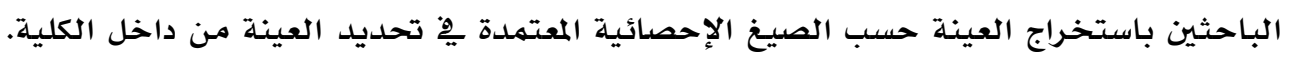

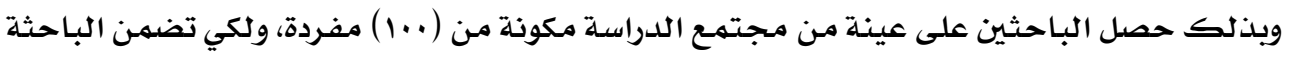

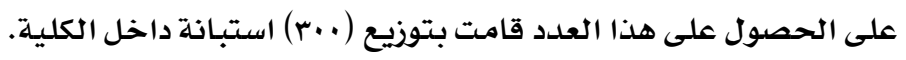

أداة الدراسة:

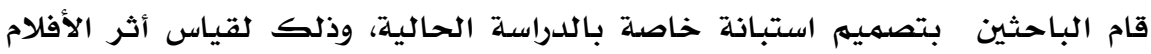

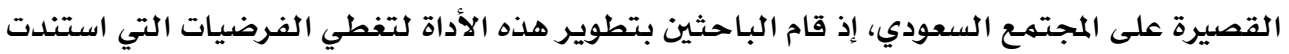

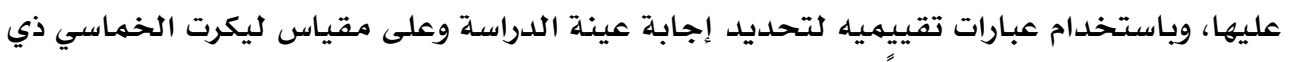

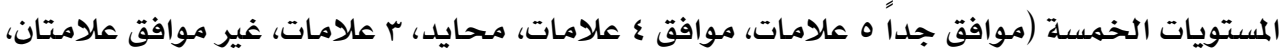

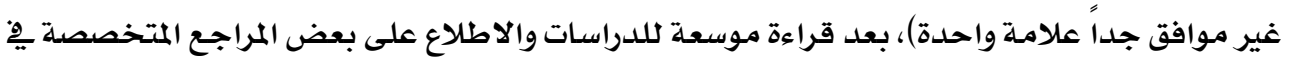

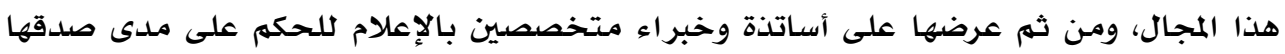

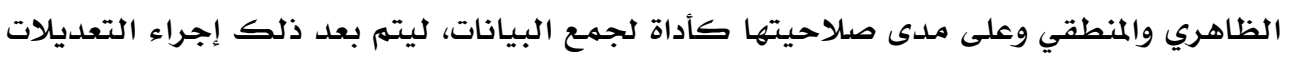
المقترحة قبل توزيعها على عينة الدراسـة.

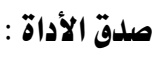

وهو اختبار قدرة الاداة على قياس ما وضعت لقياسه، بحيث يضمن عدم التحيز أو الخطأ،

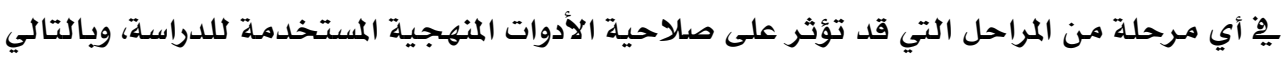

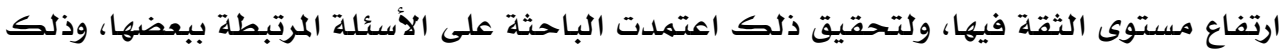

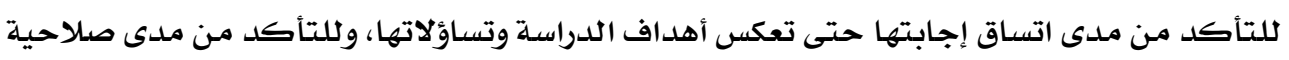

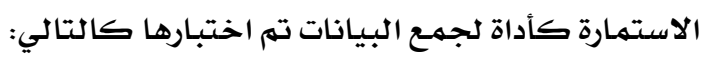

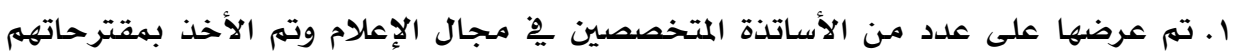

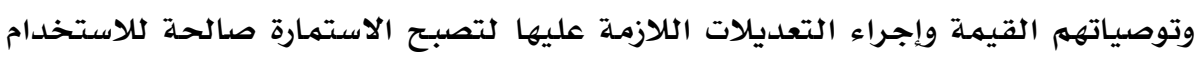
بصورة نهائية. r. تم عرض الاستبانة على بعض الخبر اء الممارسين ِِّ مجالات الإعلام ومناهج البحث. صدق الاتساق الداخلي لكلأداة :

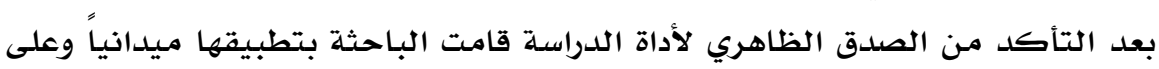

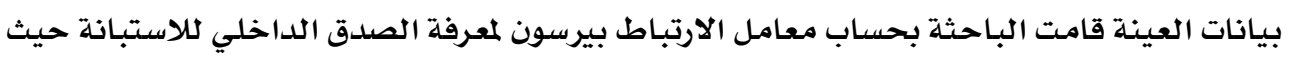


r.r. مجلة بحوث التربية النوعية - علد مه - أبريل

تم حساب معامل الارتباط بين درجة كل عبارة من عبارات الاستبانة بالدرجة الكلية للأداة كما يوضح ذلك الجدول التالي :

الجدول رقم (1) :معاملات ارتباط بيرسون لعبارات الأداة بالدرجة الكلية للأداة

\begin{tabular}{|c|c|c|c|}
\hline معامل الارتباط بالأداة & رقم العبارة & معامل الارتباط بالأداة & رقم العبارة \\
\hline $0.962^{* *}$ & 19 & $0.900^{* *}$ & 4 \\
\hline $0.878^{* *}$ & 20 & $0.884^{* *}$ & 5 \\
\hline $0.859^{* *}$ & 21 & $0.909^{* *}$ & 6 \\
\hline $0.946^{* *}$ & 22 & $0.958^{* *}$ & 7 \\
\hline $0.855^{\star *}$ & 23 & $0.915^{* *}$ & 8 \\
\hline $0.881^{* *}$ & 24 & $0.916^{\star *}$ & 9 \\
\hline $0.943^{* *}$ & 25 & $0.935^{\star *}$ & 10 \\
\hline $0.906^{\star *}$ & 26 & $0.823^{\star *}$ & 11 \\
\hline $0.915^{\star *}$ & 27 & $0.924^{* *}$ & 12 \\
\hline $0.955^{* *}$ & 28 & $0.917^{* *}$ & 13 \\
\hline $0.925^{\star *}$ & 29 & $0.955^{\star *}$ & 14 \\
\hline $0.883^{* *}$ & 30 & $0.963^{* *}$ & 15 \\
\hline $0.948^{* *}$ & 31 & $0.848^{* *}$ & 16 \\
\hline $0.890^{* *}$ & 32 & $0.850^{* *}$ & 17 \\
\hline- & - & $0.929^{* *}$ & 18 \\
\hline
\end{tabular}

يلاحظ ** دال عند مستوى الدلالة ا.., • فأقل

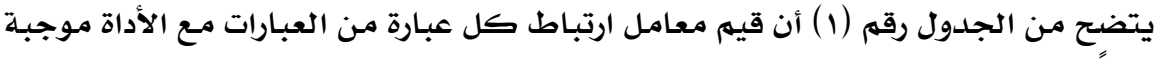

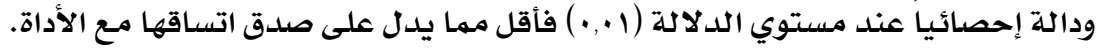

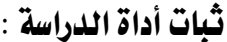

لقياس مدى ثبات أداة الدراسة (الاستبانة) استخدمت الباحثة (معادلة ألفا كرونباخ)

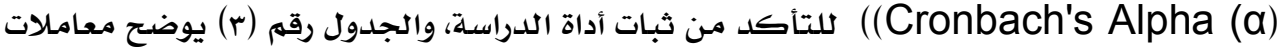

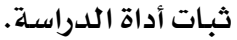

جدول رقم (r) :معامل ألفا كرونباخ لقياس ثبات أداة الدراسة

\begin{tabular}{|c|c|c|}
\hline ثبات المحور & علدد العبارات & محاور الإستبانة \\
\hline 0.9914 & 29 & الثبات العام \\
\hline
\end{tabular}




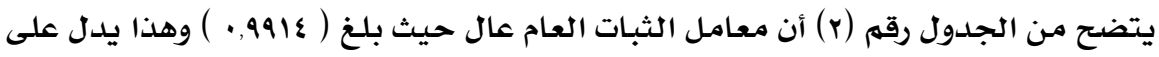

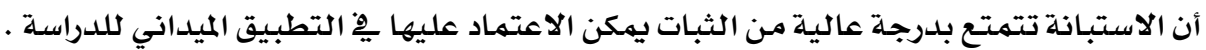

\section{أساليب المهالبة الإحصائية :}

لتحقيق أهداف الدراسـة وتحليل البيانات التي تم تجميعها، فقد تم استخدام العديد مـن الإندائ

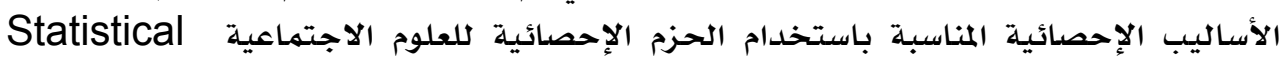
Package for Social Sciences

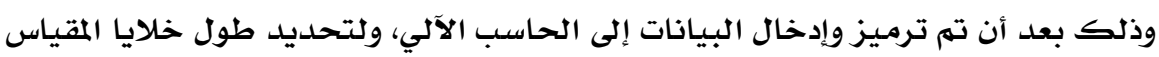

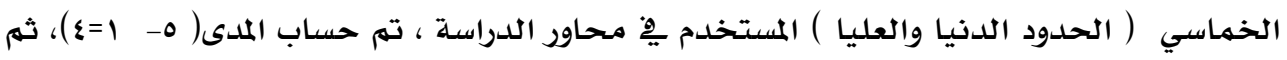

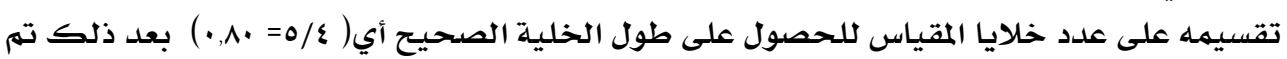

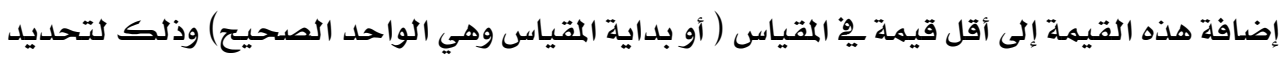

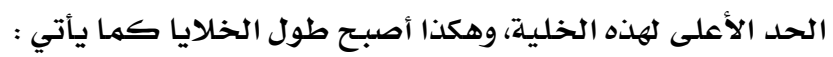

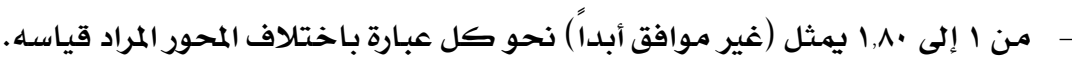

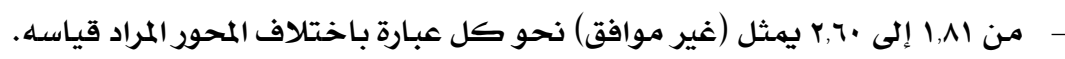

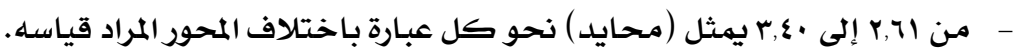

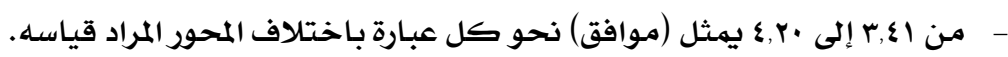

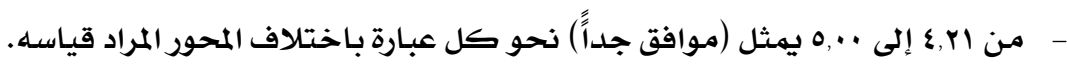

$$
\text { وبعد ذلك تم حساب المقاييس الإحصائية التالية : }
$$

ا ـ التكرارات والنسب المئوية للتعرف على الخصائص الشخصية والوظيفية لأفراد عينة الدراسـة

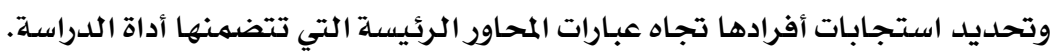

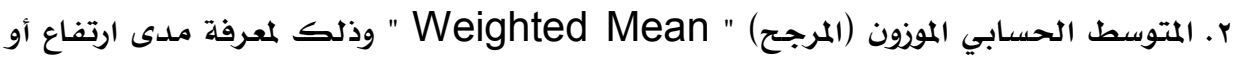

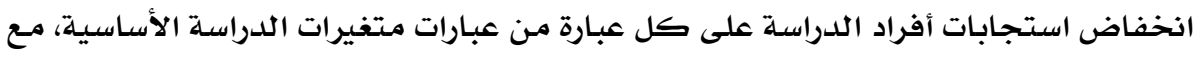

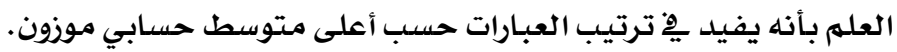

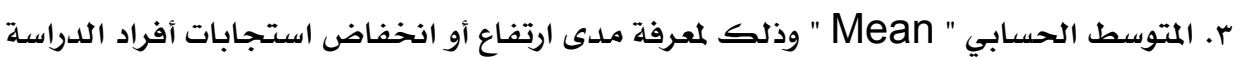

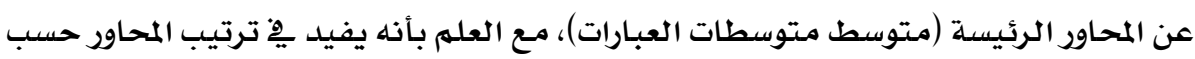
أعلى متتوسط حسـابي. ع. تم استخدام الانحراف المعياري "Standard Deviation" للتعرف على مدلى انحراف

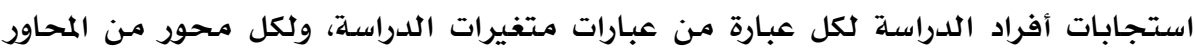

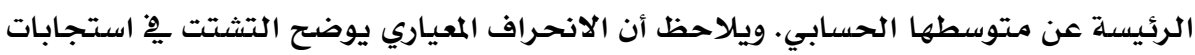

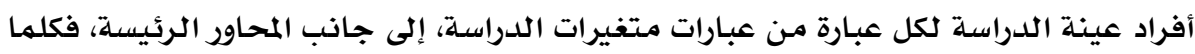

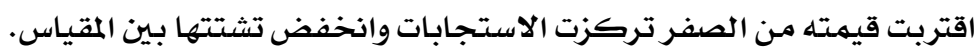




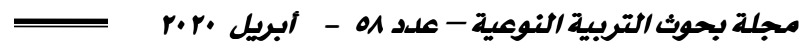

\section{المبحث الرابع : تهليل نتائج الدراسة وتفسيرها}

أولاً : وصف مفردات عينة الدراسة:

جدول رقم (r) : توزيع مفردات عينة الدراسة وفق متغير الجنس

\begin{tabular}{|c|c|c|}
\hline \multicolumn{2}{|c|}{ إناث } & \multirow[t]{2}{*}{ المتفير } \\
\hline النسبة & التكرار & \\
\hline 100.0 & 100 & \\
\hline $100 \%$ & 100 & المجموع \\
\hline
\end{tabular}

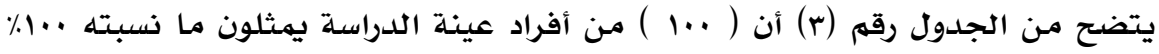

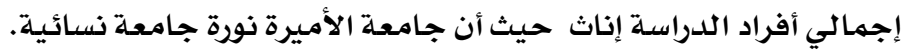

جدول رقم (ع) : توزيع مفردات عينة الدراسة وفق متغير العمر

\begin{tabular}{|c|c|c|}
\hline النسبة & التكرار & العمر \\
\hline 87.0 & 87 & من م| _ r سنة \\
\hline $13.0 \%$ & 13 & من rr _ צr سنة \\
\hline - & - & من צr _ •r سنة \\
\hline- & - & من اس _ _ سنة \\
\hline $100 \%$ & 100 & المجمموع \\
\hline
\end{tabular}

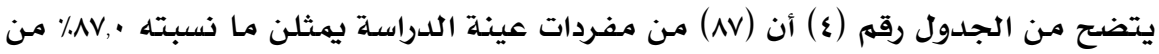

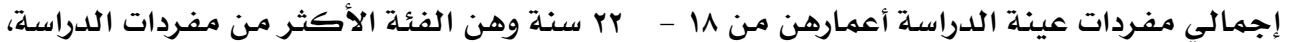

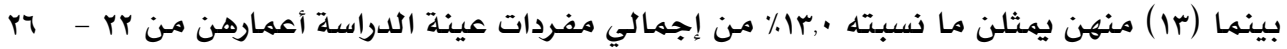
سنـة .

جلدول رقم (0) :توزيع مفردات عينة الدراسة وفق متغير السنة الدراسية

\begin{tabular}{|c|c|c|}
\hline النسبة & التكرار & السنة الدراسية \\
\hline 21.0 & 21 & الأولى \\
\hline 26.0 & 26 & الثانية \\
\hline 32.0 & 32 & الثالثة \\
\hline 21.0 & 21 & الرابعة \\
\hline $100 \%$ & 100 & المجموع \\
\hline
\end{tabular}

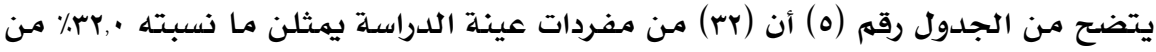

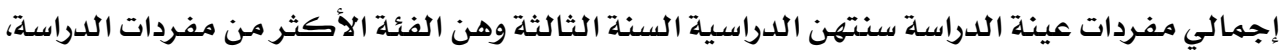




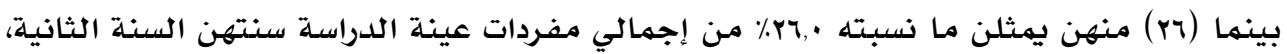

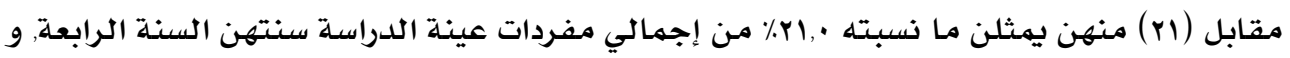

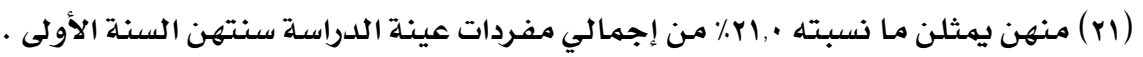

جدول رقم (؟) :ما دوافع مشاهدة الأفلام القصيرة

\begin{tabular}{|c|c|c|}
\hline \multicolumn{2}{|c|}{ داخل الجامعة } & \multirow[t]{2}{*}{ الدوافع } \\
\hline النسبة & التكرار & \\
\hline 8.0 & 8 & التعلم \\
\hline 2.0 & 2 & التعود \\
\hline 41.0 & 41 & التسلية والترفيه \\
\hline 22.0 & 22 & التفاعل مع الاخرين \\
\hline 27.0 & 27 & التفاعل مع قضايا المجتمع \\
\hline $100 \%$ & 100 & المجهوع \\
\hline
\end{tabular}

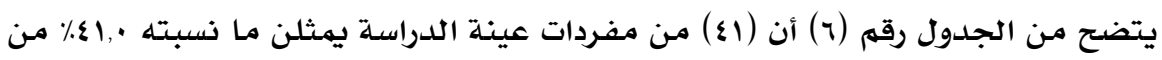

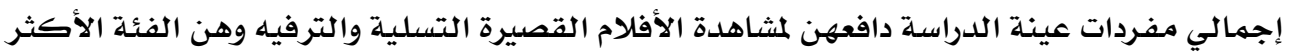

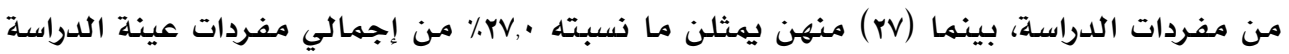

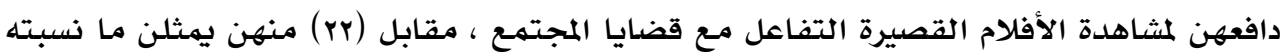

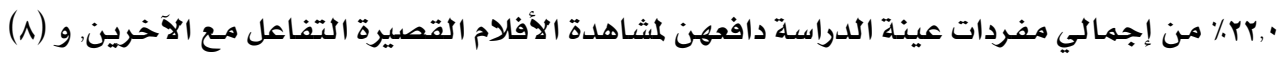

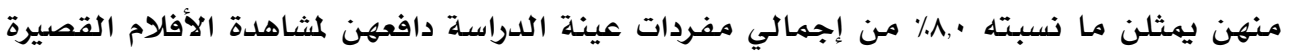

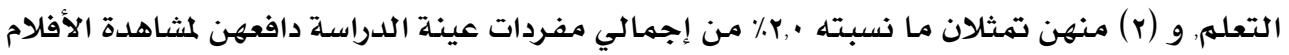
القصيرة التعود .

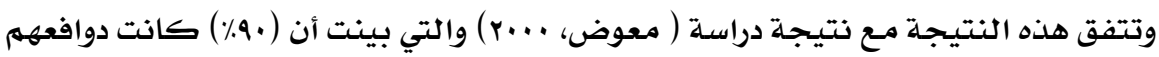

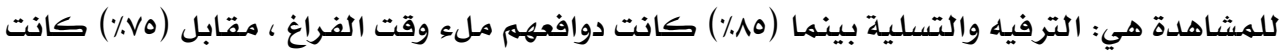

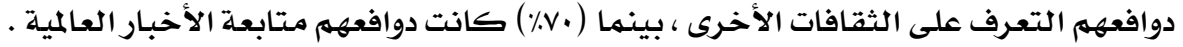

جدول رقم (v) : ما مدى مشاهدة الشباب السعودي للأفلام القصيرة السعودية

\begin{tabular}{|c|c|c|}
\hline النسبة & التكرار & ملى المشاهدة \\
\hline 25.0 & 25 & يومياً \\
\hline 42.0 & 42 & مرة في الأسبوع \\
\hline 33.0 & 33 & من r ـ ـ مرات في الأسبوع \\
\hline $100 \%$ & 100 & المجموع \\
\hline
\end{tabular}




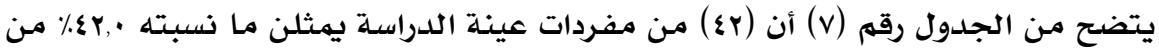

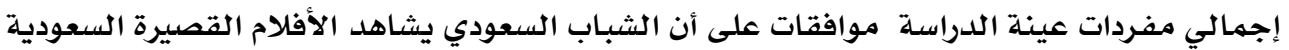

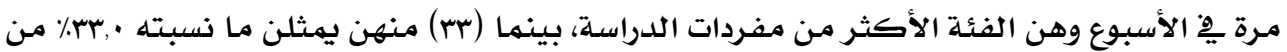

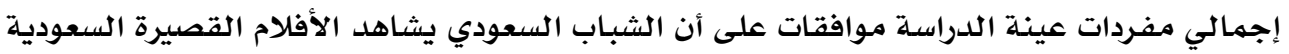

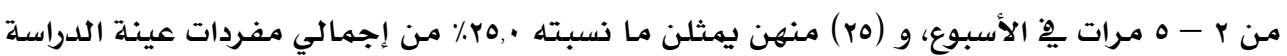

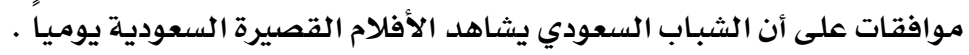

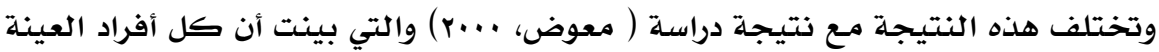

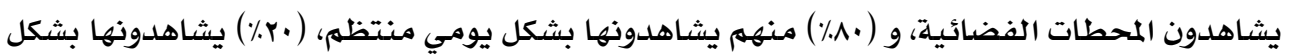

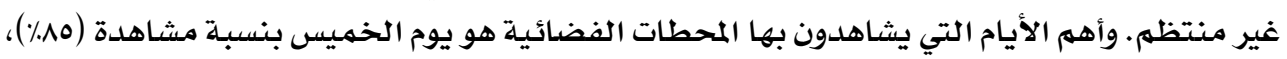

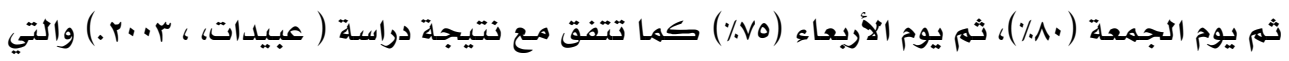

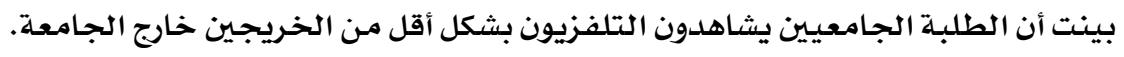
جدول رقم (م) : كيف أجد الأفلام القصيرة السعودية

\begin{tabular}{|c|c|c|}
\hline النسبة & التكرار & \\
\hline 51.0 & 51 & ابجث عنها \\
\hline 21.0 & 21 & تصلني من صديق \\
\hline 28.0 & 28 & أتواصل مع منتجي الأفلام القصيرة \\
\hline $100 \%$ & 100 & المجموع \\
\hline
\end{tabular}

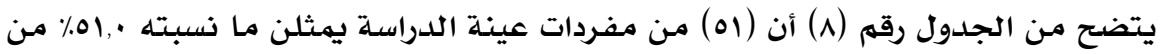

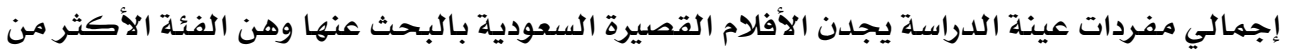

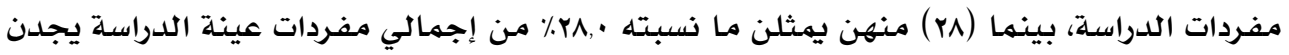

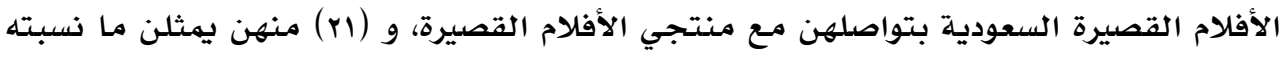

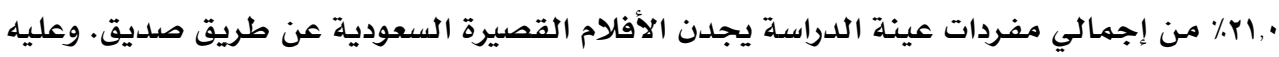

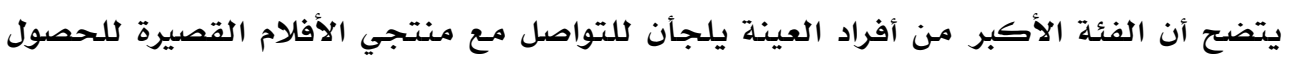
عليها.

أثر الأفلام القصيرة من وجهة نظر الطالبات:

للتعرف على أثر الأفلام القصيرة يتحين علينا حساب التكرارات والنسب المئوية والمتوسطات

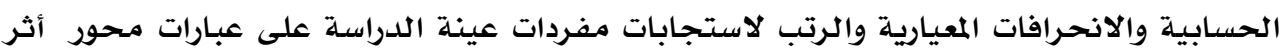

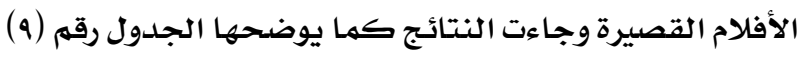


جدول رقم (9) :استجابات مفردات عينة الدراسة على عبارات محور أثر الأفلام القصيرة مرتبة تنازلياً حترب

متوسطات الموافقة

\begin{tabular}{|c|c|c|c|c|c|c|c|c|c|c|}
\hline \multirow{2}{*}{ 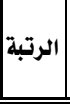 } & \multirow{2}{*}{ الانحياري } & \multirow{2}{*}{ الحتوسط } & \multicolumn{5}{|c|}{ 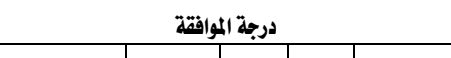 } & \multirow{2}{*}{ 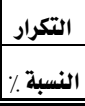 } & \multirow{2}{*}{ العبارة } & \multirow{2}{*}{ رقم } \\
\hline & & & غير موافق أبداً & غير موافق & محايل & موافق & موافق جداً & & & \\
\hline \multirow{2}{*}{1} & \multirow{2}{*}{0.796} & \multirow{2}{*}{4.35} & - & 2 & 14 & 31 & 53 & ك & \multirow{2}{*}{ |أسلوب عرض الأفلام القصيرة تخاطب الشباب بطريقة } & \multirow{2}{*}{6} \\
\hline & & & - & 2.0 & 14.0 & 31.0 & 53.0 & $\%$ & & \\
\hline \multirow{2}{*}{2} & \multirow{2}{*}{0.759} & \multirow{2}{*}{4.10} & 1 & 1 & 15 & 53 & 30 & ك & \multirow{2}{*}{ | ترفع الموضوعات المطروحة في الأفلام القصيرة من مستوى } & \multirow{2}{*}{20} \\
\hline & & & 1.0 & 1.0 & 15.0 & 53.0 & 30.0 & $\%$ & & \\
\hline \multirow{2}{*}{3} & \multirow{2}{*}{1.092} & \multirow{2}{*}{4.02} & - & 12 & 22 & 18 & 48 & ك & \multirow{2}{*}{ |يتيمز مضمون الأفلام القصيرة بالتعدد والتنوع } & \multirow{2}{*}{9} \\
\hline & & & - & 12.0 & 22.0 & 18.0 & 48.0 & $\%$ & & \\
\hline \multirow{2}{*}{4} & \multirow[t]{2}{*}{0.772} & \multirow[t]{2}{*}{3.99} & 1 & 2 & 18 & 55 & 24 & ك & \multirow{2}{*}{ |تغطيها } & \multirow{2}{*}{11} \\
\hline & & & 1.0 & 2.0 & 18.0 & 55.0 & 24.0 & $\%$ & & \\
\hline \multirow{2}{*}{5} & 0.772 & 3.99 & 1 & 4 & 21 & 45 & 29 & ك & & \\
\hline & & & 1.0 & 4.0 & 21.0 & 45.0 & 29.0 & $\%$ & & 21 \\
\hline 6 & 0.839 & 3.94 & 1 & 5 & 17 & 53 & 24 & ك & تراعي المادة المعروضة في الأفلام القصيرة العادات والقيه| & 12 \\
\hline $\mathbf{0}$ & & & 1.0 & 5.0 & 17.0 & 53.0 & 24.0 & $\%$ & الإسلامية & 12 \\
\hline 7 & 0.728 & 3.93 & 1 & 3 & 15 & 64 & 17 & ك & محتوى مادة الأفلام القصيرة المعروضة مناسبة من حيث| & 10 \\
\hline 1 & & & 1.0 & 3.0 & 15.0 & 64.0 & 17.0 & $\%$ & الشكل والإخراج & 10 \\
\hline $\mathbf{9}$ & 0.769 & 3.93 & - & 3 & 24 & $\mathbf{5 0}$ & 23 & ك & تتميز الأفلام القصيرة بتقديم محتوى ذو مضامين ترفيهية & $\mathbf{0}$ \\
\hline $\mathbf{0}$ & & & - & 3.0 & 24.0 & 50.0 & 23.0 & $\%$ & 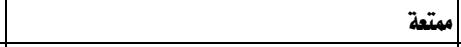 & 0 \\
\hline $\mathbf{0}$ & 0.870 & 3.90 & 1 & 4 & 25 & 44 & 26 & ك & |تمتاز الأفلام القصيرة بأنها ذات طابع تفاعلي إنسانياً & 14 \\
\hline 9 & & & 1.0 & 4.0 & 25.0 & 44.0 & 26.0 & $\%$ & وروحياً & 14 \\
\hline 10 & 0.870 & 3.90 & 1 & 8 & 17 & $\mathbf{5 0}$ & 24 & ك & هناك تناسق وتناغم بين الصوت والموسيقى المصاحبة| & 16 \\
\hline 10 & & & 1.0 & 8.0 & 17.0 & 50.0 & 24.0 & $\%$ & |للأفلام القصيرة مع محتوى المادة المعروضة & 10 \\
\hline 11 & 0.775 & 3.84 & - & 6 & 21 & 56 & 17 & ك & 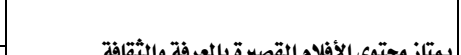 & 15 \\
\hline 11 & & & - & 6.0 & 21.0 & 56.0 & 17.0 & $\%$ & | يمتار محتوى الافلام الفصيره بالمعرقه وام & 15 \\
\hline 12 & 0.770 & 3.82 & - & 5 & 25 & 53 & 17 & ك & |الموضوعات المطروحة الأفلام القصيرة تناسب القيه| & 18 \\
\hline 12 & & & - & 5.0 & 25.0 & 53.0 & 17.0 & $\%$ & الدينية & 18 \\
\hline 12 & 0.800 & 3.81 & - & 7 & 22 & 54 & 17 & ك & تسهم المضامين الإيجابية التي تعرضها الأفلام القصيرة في & 21 \\
\hline 13 & & & - & 7.0 & 22.0 & 54.0 & 17.0 & $\%$ & تفيير مفاهيمي نحو مختلف المواضييع & 24 \\
\hline 14 & 0.943 & 3.80 & - & 12 & 20 & 44 & 24 & ك & & 22 \\
\hline 14 & & & - & 12.0 & 20.0 & 44.0 & 24.0 & $\%$ & 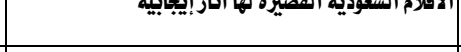 & 22 \\
\hline & 0.991 & 3.78 & 3 & 7 & 23 & 43 & 24 & ك & & \\
\hline 15 & & & 3.0 & 7.0 & 23.0 & 43.0 & 24.0 & $\%$ & |تولي الافلام القصيرة الاهتمام الاكبر بالقصايا العربية & 19 \\
\hline
\end{tabular}


مجلة بحوث التربية النوعية - عدد 1ه - r.r. مجبريل

(ه) (هابع جدول رقم

\begin{tabular}{|c|c|c|c|c|c|c|c|c|c|c|}
\hline \multirow{2}{*}{ 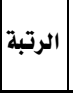 } & \multirow{2}{*}{ |الانعياري } & \multirow{2}{*}{ | الحتوسط } & \multicolumn{5}{|c|}{ درجة الموافقة } & \multirow{2}{*}{ | التكرار } & \multirow{2}{*}{ | } & \multirow{2}{*}{ العبارة } \\
\hline & & & غير موافق ابلا & 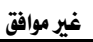 & 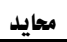 & 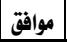 & موافق جداً & & & \\
\hline \multirow{2}{*}{16} & \multirow[t]{2}{*}{0.848} & \multirow[t]{2}{*}{3.78} & - & 7 & 28 & 45 & 20 & $ك$ & \multirow{2}{*}{ | الايلية } & \multirow{2}{*}{13} \\
\hline & & & - & 7.0 & 28.0 & 45.0 & 20.0 & $\%$ & & \\
\hline \multirow{2}{*}{17} & \multirow[t]{2}{*}{0.927} & \multirow[t]{2}{*}{3.78} & 2 & 6 & 26 & 44 & 22 & ك & \multirow{2}{*}{ | الششاهدة الأفلام القصيرة الققدمة تشبع حاجاتي في متعة } & \multirow{2}{*}{7} \\
\hline & & & 6.0 & 26.0 & 44.0 & 22.0 & 20.0 & $\%$ & & \\
\hline \multirow{2}{*}{18} & \multirow[t]{2}{*}{0.973} & \multirow[t]{2}{*}{3.77} & 3 & 6 & 25 & 43 & 23 & ك & \multirow{2}{*}{ تقدم الأفلام القصيرة السعودية محتواها بأسلوب جذاب } & \multirow{2}{*}{28} \\
\hline & & & 3.0 & 6.0 & 25.0 & 43.0 & 23.0 & $\%$ & & \\
\hline \multirow{2}{*}{19} & \multirow[t]{2}{*}{0.821} & \multirow[t]{2}{*}{3.75} & - & 9 & 22 & 54 & 15 & ك & \multirow{2}{*}{ 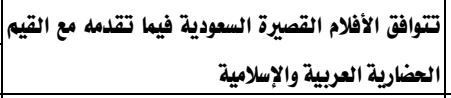 } & \multirow{2}{*}{30} \\
\hline & & & - & 9.0 & 22.0 & 54.0 & 15.0 & $\%$ & & \\
\hline \multirow{2}{*}{20} & 0.883 & 3.74 & 1 & 7 & 28 & 45 & 19 & ك & الموضوعات المطروحة في الأفلام القصيرة من ضمن & 17 \\
\hline & & & 1.0 & 7.0 & 28.0 & 45.0 & 19.0 & $\%$ & | اهتمامي & \\
\hline & 0.877 & 3.67 & - & 12 & 24 & 49 & 15 & ك & & \\
\hline 1 & & & - & 12.0 & 24.0 & 49.0 & 15.0 & $\%$ & 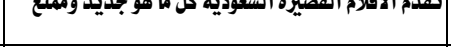 & 25 \\
\hline & 0.934 & 3.66 & - & 16 & 18 & 50 & 16 & $ك$ & تقتاز الأفلام القصيرة السعودية بأنها منافسة ثثيلاتها من & \\
\hline & & & - & 16.0 & 18.0 & 50.0 & 16.0 & $\%$ & | الأفلام العربية القصيرة & \\
\hline & & & 2 & 8 & 31 & 43 & 16 & ك & تقدم الأفلام القصيرة السعودية كل ما هو ملائم للذوق & \\
\hline 20 & & 3000 & 2.0 & 8.0 & 31.0 & 43.0 & 16.0 & $\%$ & & \\
\hline & 2027 & & 1 & 8 & 30 & 49 & 12 & ك & تتاسب الأفلام القصيرة السعودية بعا تعرضه مختلف & \\
\hline & & | & 1.0 & 8.0 & 30.0 & 49.0 & 12.0 & $\%$ & فئات المجتمع & \\
\hline 25 & 202 & 62 & 5 & 3 & 36 & 37 & 19 & ك & أعتقد أن الأفلام القصيرة المقدمة تتفاعل مع أحداث & \\
\hline 23 & נצלים & 0.02 & 5.0 & 3.0 & 36.0 & 37.0 & 19.0 & $\%$ & العالم الإسلامي & J \\
\hline 26 & 030 & 362 & 1 & 5 & 48 & 23 & 23 & ك & تسهم الأفلام القصيرة في تشكيل اتجاهاتي حول & \\
\hline 20 & 0.50 & 0.02 & 1.0 & 8.0 & 30.0 & 49.0 & 12.0 & $\%$ & الموضوعات التي تعالجها & \\
\hline 27 & $10 ?$ & 350 & 5 & 12 & 23 & 39 & 21 & ك & أفضل مشاهدة الأفلام القصيرة السعودية على الأفلام & 1 \\
\hline & & & 5.0 & 12.0 & 23.0 & 39.0 & 21.0 & $\%$ & القصيرة العربية الأخرى & \\
\hline 20 & | & 350 & 2 & 8 & 44 & 30 & 16 & ك & الموضوعات التي تقدمها الأفلام القصيرة السعودية & \\
\hline 20 & 0.921 & 3.00 & 2.0 & 8.0 & 44.0 & 30.0 & 16.0 & $\%$ & متقدمة عن ما تقدمه الأفلام القصيرة العربية & \\
\hline & & & 22 & 39 & 18 & 10 & 11 & ك & & \\
\hline 29 & 1.251 & 2.49 & 22.0 & 39.0 & 18.0 & 10.0 & 11.0 & $\%$ & |الافلام السص & 23 \\
\hline & 842 & 3.77 & & & & & & 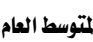 & & \\
\hline
\end{tabular}

من خلال النتائج الموضحة أعلاه يتضح أن مفردات عينة الدراسـة موافقات على أثر الأفلام

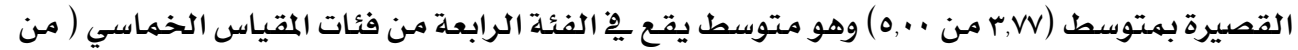

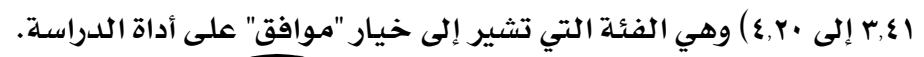


ويتضح من النتائج أن هناك تفاوت ِِّ موافقة مفردات عينة الدراسـة على أثر الأفلام

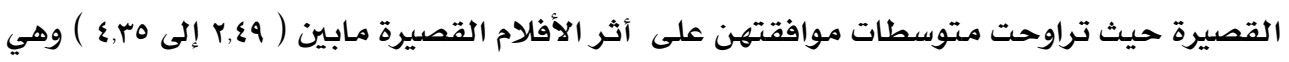

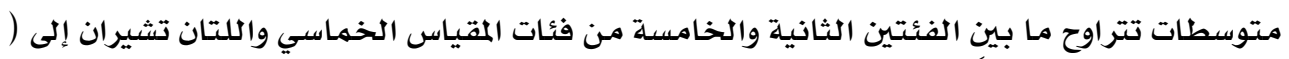

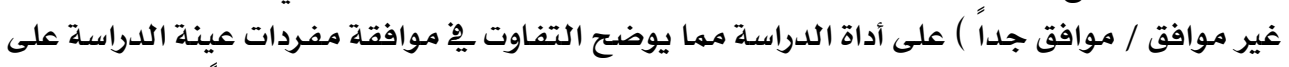

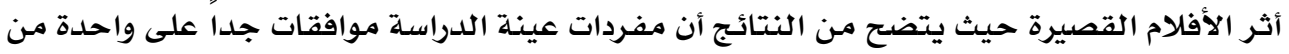

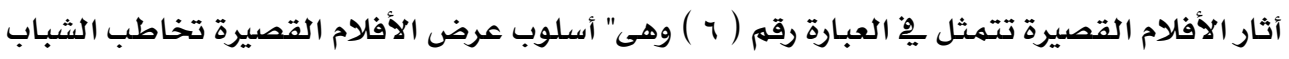

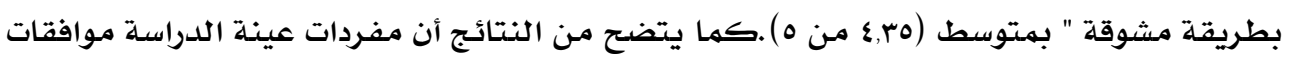

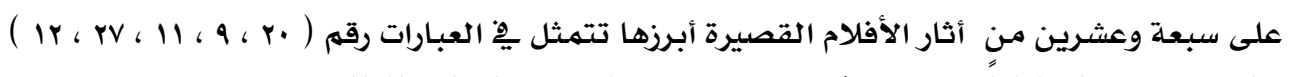

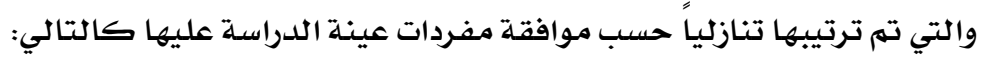

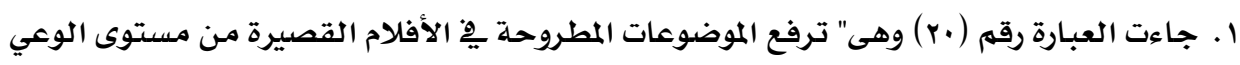

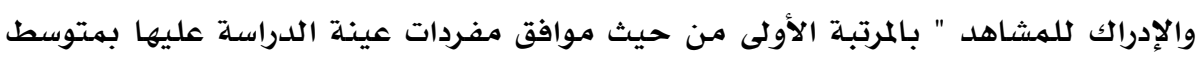

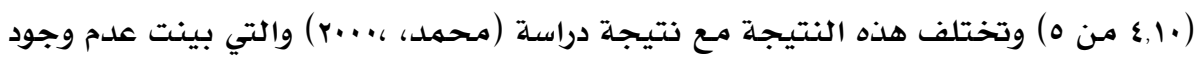

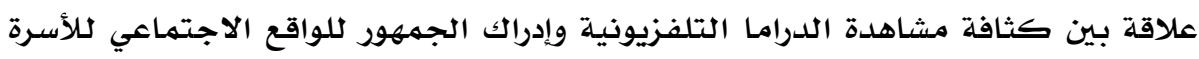
r. جاءت العبارة رقم (ه) وهى" يتميز مضمون الأفلام القصيرة بالتعدد والتنوع " بالمرتبة الثانية

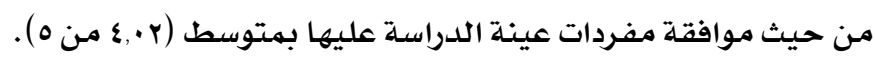

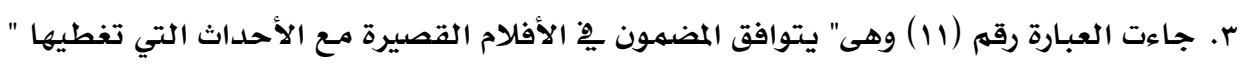

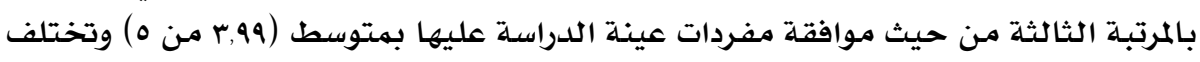

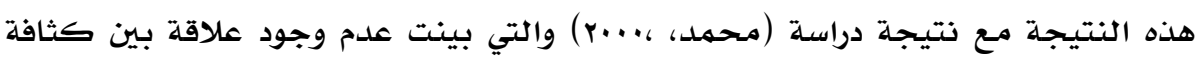

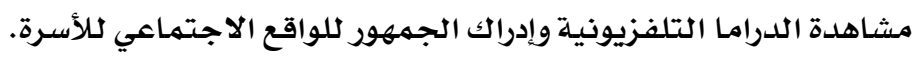
ع. جاءت العبارة رقم (rV) وهى" تطرح الأفلام القصيرة السعودية القضايا الواقعية " بالمرتبلة

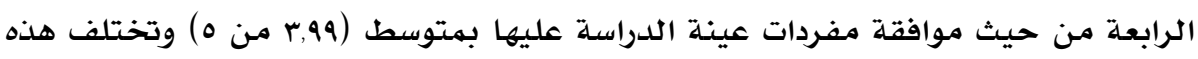

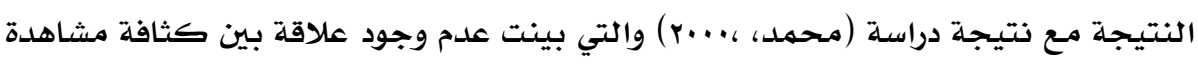

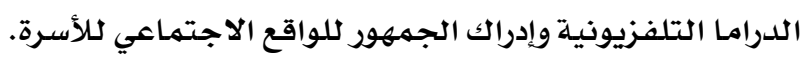

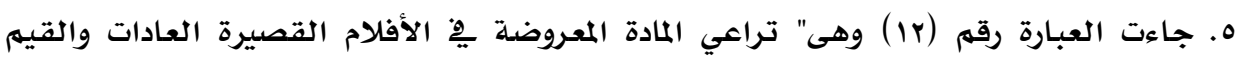

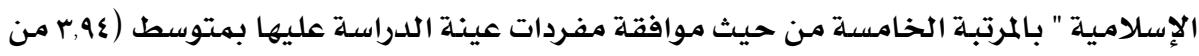

كهما يتضح من النتائج أن مفردات عينة الدراسـة غير موافقات على واحدة من أثار الأفلام

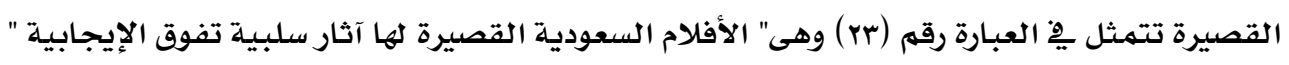

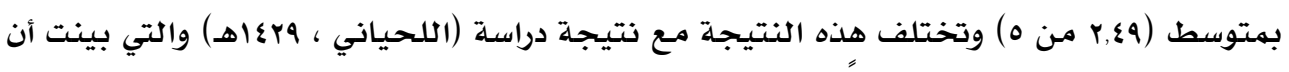

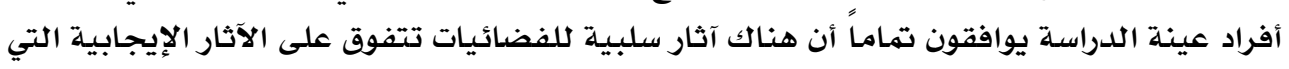
تقدمها تلك الفضائيات. 
يتضح من خلال النتائج الموضحة أعلاه أن أبرز ملامـح اتجاهات طالبات كلية التصاميهم

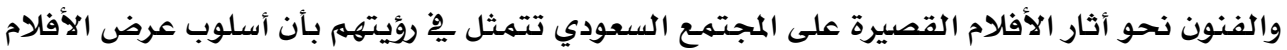

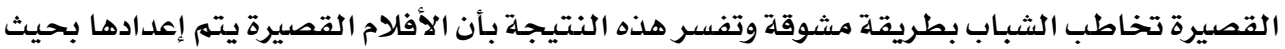

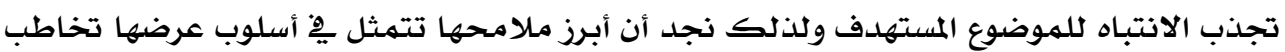
الشباب بطريقة مشوقة.

\section{نتائج الدراسة وتوصياتها}

أهم تتائج اللدراسة :

\section{وصف مفردات عينة الدراسة :-}

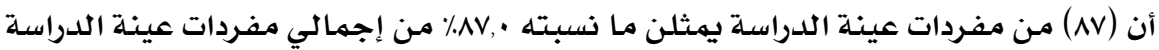

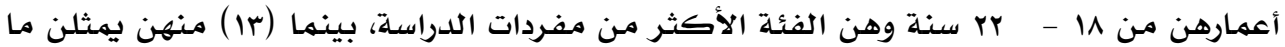

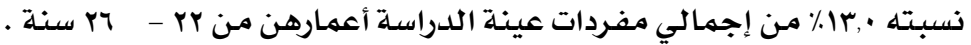

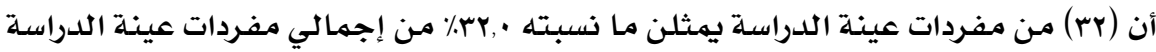

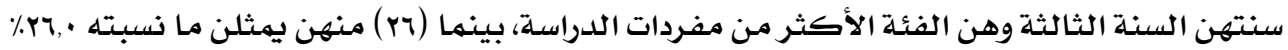

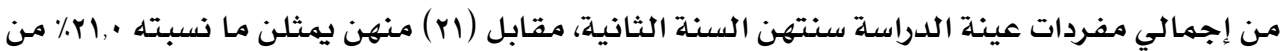

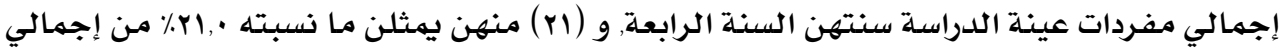

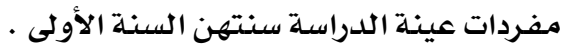
أن (اء) من مفردات عينة الدراسـة يمثلن ما نسبته • ,اءع٪ من إجمالي مفردات عينة الدراسة

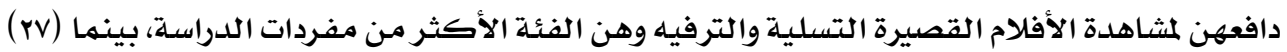

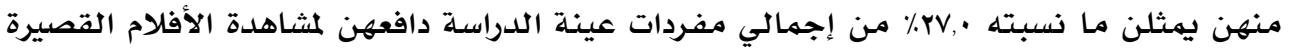

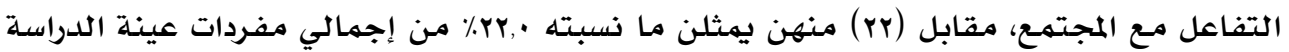

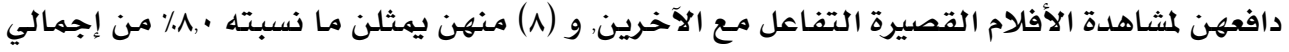

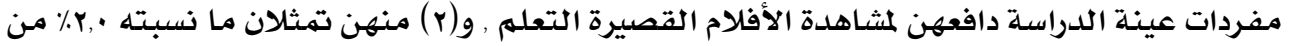

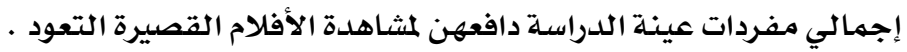

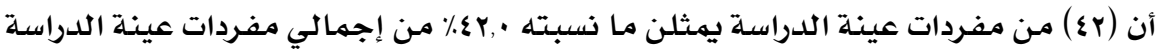

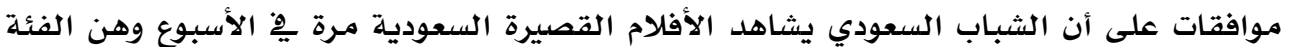

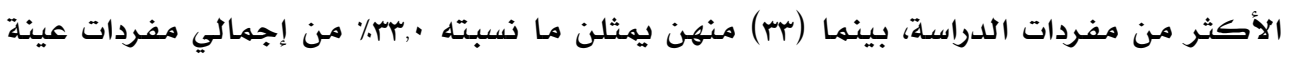

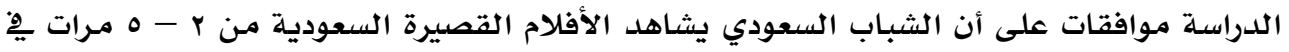

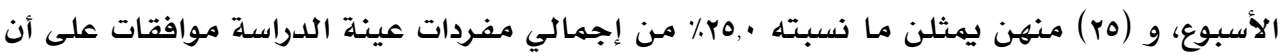

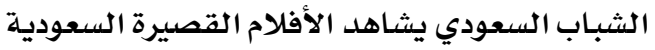

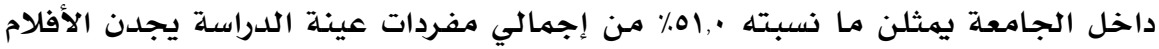

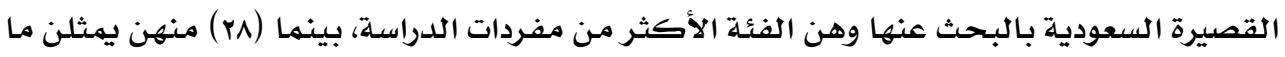




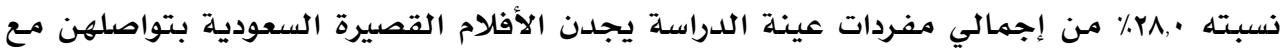

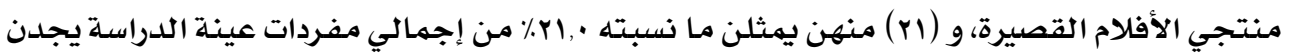

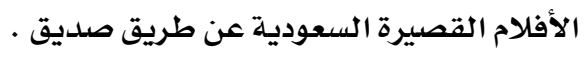

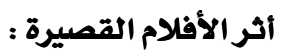

• مفردات عينة الدراسـة موافقات على أثر الأفلام القصيرة.

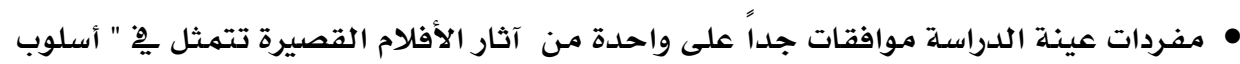

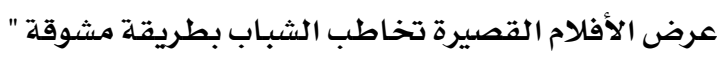
مفردات عينة الدراسة موافقات على سبعة وعشرين من آثار الأفلام القصيرة أبرزها تتمثل ِِِ؛

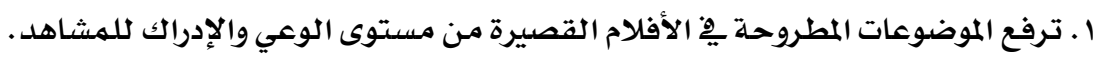
r ب يتيمز مضمون الأفلام القصيرة بالتعدد والتنوع. r. يتوافق المضمون يِّ الأفلام القصيرة مـع الأحداث التي تغطيها. ع. تطرح الأفلام القصيرة السعودية القضايا الواقعية.

ه. تراعي المادة المعروضدة ِِّ الأفلام القصيرة العادات والقيه الإسلاميلة.

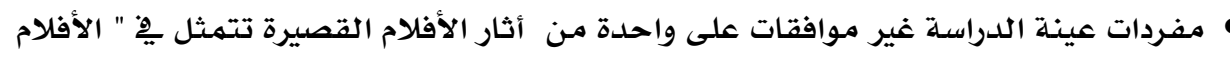

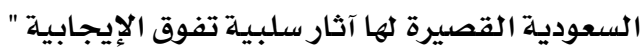
توصيات الدراسة : ا. اتخاذ إجراءات أكثر فاعلية للحد من الآثار السلبية للأفلام القصيرة على المجتمـع السعودي.

r. التوصية بتحسين مستوى التشويق يِ أسلوب عرض الأفلام القصيرة .

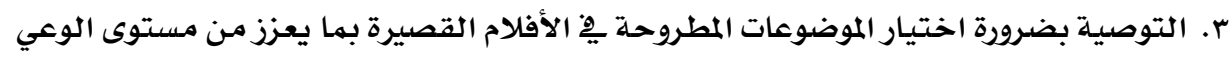
والإدراك للمشاهد.

ع. التوصية بمدى أهمية تحقيق التعدد والتنوع بِّ مضمون الأفلام القصيرة. ه. الاهتمام بهراعاة توافق المضمون يِّ الأفلام القصيرة مـع الأحداث التي تغطيها. 7. التوصية بضرورة مـراعاة المادة المعروضة يِّ الأفلام القصيرة للعادات والقيم الإسلامية. V. إقامة ورث عمل وندوات علمية للنقاش و البحث يِّ كيفية الحد من الأثار السلبية لتلأفلام

$$
\text { القصيرة على المجتهـع السعودي. }
$$

$$
\text { ^. إجراء تقويم دوري لواقع تأثير الأفلام القصيرة على المجتمع السعودي. }
$$

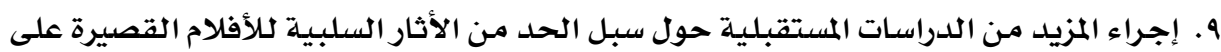

$$
\text { المجتمـع السعودي. }
$$




\section{أولاً: المراجع باللفة العربية}

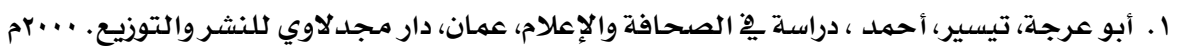

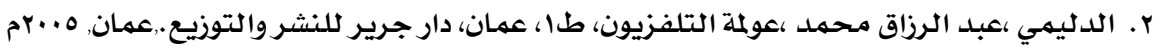

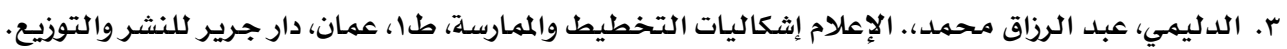
ar.l.

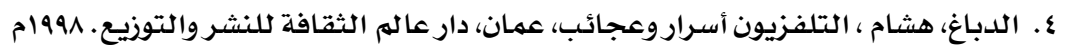

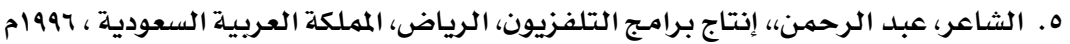

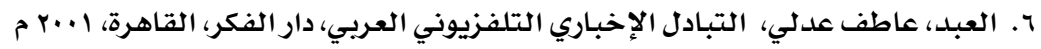

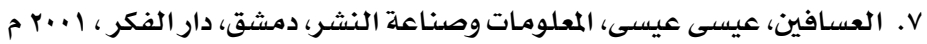

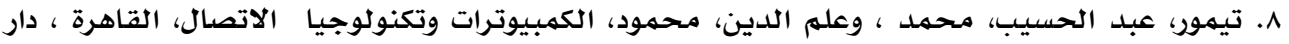

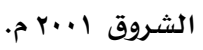

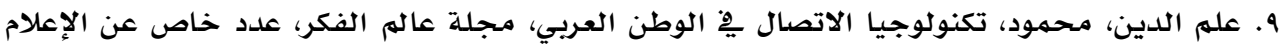

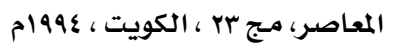

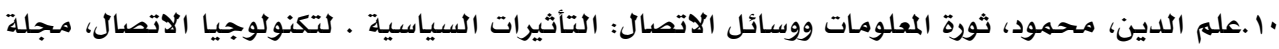
السياسة الدولية ، ع991م.

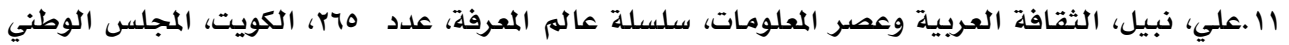

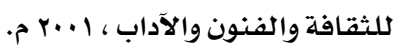

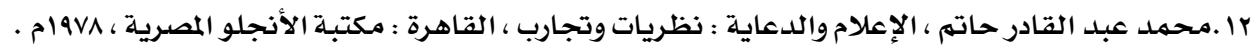

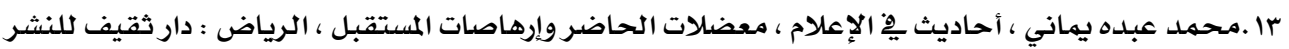

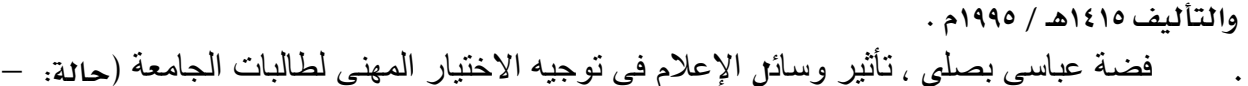

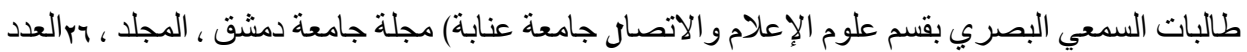

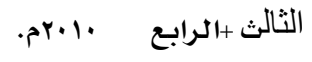

\section{ثانياً: المراجع باللفة الأجنبية}

1. Charles, S. (2003). The Quality of television program content and its relationship to achievement and behavior in late- latency age student. $\mathrm{PhD}$. IRIC, Boston College.

2. Gomez, O. (2008) commercial, Television and student education in Mexico. Edd-irric. Harvard University. P.309.

3. Ipsos Stat, (2007), "National Media Analysis NMA Jordan 2007 TV Section", Amman. 
4. Urbahn, Keith, (July 26, 2004). Reporting the Truth: Media Perceptions, Preferences, and Practices among Young UAE Nationals. Report submitted to the US Embassy, Abu Dhabi, UAE.

5. Bradley, Ann, (March 16, 2005). Media-Use Study Finds Youths Increasingly Multi-Tasking. Education week, Vol. 24, Issue 27, p.4.

6. Robison, Gordon, (June 2005). The Rest of the Arab World. USC Center on Public Diplomacy, University of Southern California, Los Angeles, California. From: www.uscpublicdiplomacy.org.

7. Tuggle, C. A, Huffman, Suzanne, and Rosengard, Dana Scott, (April 2007). Reporting Live From the Scene: Enough to Attract the 18-24 Audience? Journal of Broadcasting \& Electronic Media. Vol. 51, Issue 1, p. 58.

8. Anonymous, (March 19, 2008). Favorite TV Channel Survey: Digital/Satellite Channels. From: http://brandtao.wordpress.com

\section{ثالثًا: الرسائل الجامعية}

ا . بلغيث، سلطان، واقع إسهام الفضائيات العربية ِيخ نشر الثقافة العربية الإسلامية، دراسـة ميدانية من وجهة

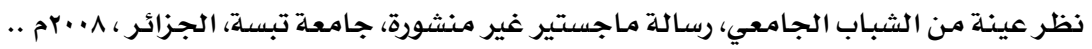

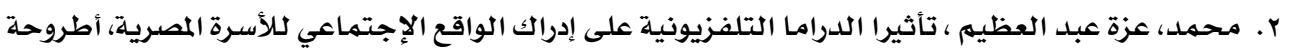

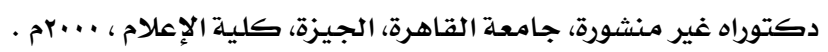

r. محمدل، نديم ربحي، بعنوان: اتجاهات طلبة الجامعات الاردنية نحو المحطات الفضائية العربية، رسالة

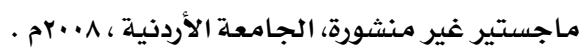

ع. معوض، محمد، وعبد الجليل، عبد الباسط، بعنوان: علاقة شباب دولة الكويت بالقنوات الفضائية، رسالة

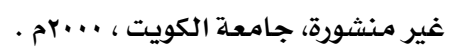

ه. عبيدات، ذوقان عبد الله , دراسـة بعنوان: الفضائيات والانترنت معالجة السلبيات لدى الناشئة تعزيزا

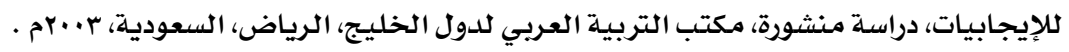

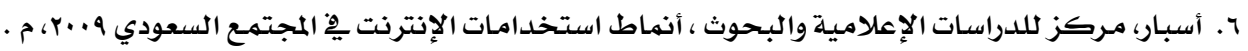
V. اللحياني، خضر، دراسـة بعنوان: أثر الفضائيات على المراهقين والمراهقات يِّ المملكة العربية السعودية من وجهة نظر التربويـين والتربويات. رسالة ماجستير كلية التربية، قسىم الإعلام جامعة كولومبوس، الولايات

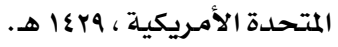

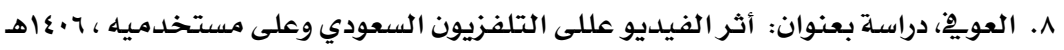
رابعاً: الصحف والجرائل والمواقع الإلكترونية

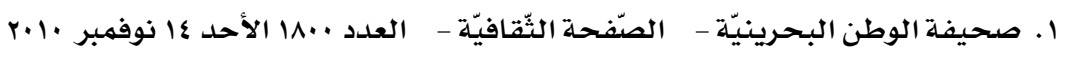
r · جريدة المدينة المنورة ، رحلة يِّ أفكار عبد الله بلخير ، العدد جrrT ، rا رجب ع • عاهـ. 
ب r.r. r. مجلة بحوث التربية النوعية - علد

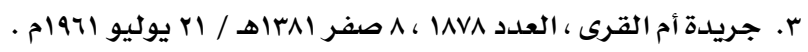

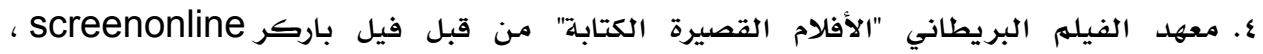
م. WWWw.bfi.org.uk

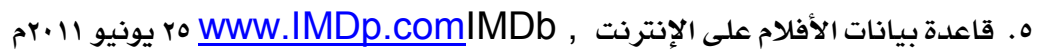
91ST ACADEMY AWARDS SPECIAL RULES FOR THE , SHORT FILM AWARDS https://www.oscars.org/sites/oscars/files/91aa short films.pdf

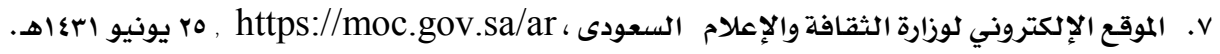

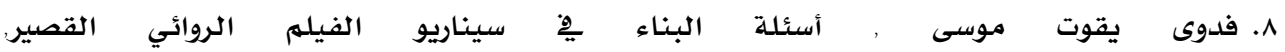

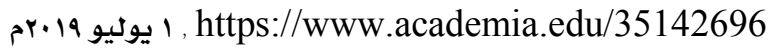
http://www.okaz.com.sa/new/Issues .9 